\title{
População, recursos naturais e poder territorializado: uma perspectiva teórica supratemporal
}

\author{
Ralfo Matos*
}

\begin{abstract}
Esse ensaio discute relações sociopolíticas e territoriais que recobrem a dinâmica demográfica, os recursos naturais e o exercício do poder em diferentes momentos históricos. A reflexão sobre a China contemporânea e seu desenvolvimento econômico fortemente consumidor de recursos naturais serve de parâmetro para estabelecer conexões com outros tempos históricos nos quais a combinação em tríade poder, recursos e população sempre esteve presente. Quatro tempos históricos são sublinhados: o da passagem do Pleistoceno para o Holoceno; o do florescimento da civilização grega; o da reestruturação europeia do século XVI; e o da arrancada industrializante a partir de fins do século XVIII, que introduziu um longo período de hegemonia econômica europeia. Formas de poder político, população e os recursos de subsistência e de proeminência são cruciais para o entendimento da tessitura de projetos de expansão protagonizados por países europeus e não europeus, especialmente a partir do século XIX, momento em que rivalidades e interesses geopoliticos tornam-se explosivos e estruturam divisões internacionais do trabalho que se reproduziram por muito tempo. As análises e os exemplos arrolados permitem indagar se o ideário expansionista não estaria assumindo hoje novas roupagens, ainda que não mais exclusivamente territorialista. Há fortes indícios de que uma memória coletiva grandiloquente realimenta antigos mitos fundadores que valorizam identidades nacionais em ambientes de pouca racionalidade, nos quais a perspectiva de maximização de lucros e oportunidades contagia a todos.
\end{abstract}

Palavras Chaves: População e história. População e recursos. População e geopolítica.

\section{Introdução}

Pensar em população e recursos naturais, hoje, é pensar na China. Com seus $9.561 .000 \mathrm{~km}^{2}$, a República Popular da China possui mais de 1,35 bilhão de habitantes, o que equivale a $1 / 5$ da população mundial. Nesses números, há quase 770 milhões de pessoas ainda residindo em áreas rurais e algo em torno de 300 milhões de consumidores de bens e serviços modernos moran- do em cidades relativamente próximas da franja litorânea, na porção nordeste-leste-sudeste do país. A restrição de espaços adequados à ocupação humana é notável, já que cerca de um terço do território é desértico e inóspito. Mas sua formidável expansão econômica nos últimos 30 anos tem impressionado analistas do mundo inteiro, vários deles descrentes da possibilidade de um país sustentar por tanto tempo um crescimento do PIB a taxas próximas de $9 \%$

\footnotetext{
* Doutor em demografia, professor titular do Departamento de Geografia do IGC/UFMG (ralfo@ufmg.br).
} 
ao ano. Em 2009, o PIB chinês situou-se em torno de cinco trilhões de dólares. Em 2010, ultrapassando o Japão, galgou o posto de segunda economia do planeta, tornando-se um dos motores do comércio mundial, inclusive recuperando-se rapidamente dos efeitos da crise internacional de 2008, ainda não debelada nas economias centrais.

Tudo isso impressiona ao se levar em conta que até 20 anos atrás $80 \%$ da população chinesa vivia da agricultura. A herança milenar de traços rurais legou um sistema familiar baseado: em estruturas culturais de forte expressão territorial que se assemelham a pequenos estados clânicos; em um patriarcado autocrático sustentado por trabalho coletivo, disciplina, obediência e lealdade dos filhos para com os pais; em casamentos arranjados, sujeição e subordinação feminina à família do marido (camponesas mantidas no analfabetismo e sem acesso à propriedade); na valorização excessiva do filho homem por herdar o nome da família e ser responsável pela terra e pelos cuidados aos idosos; e na utilização do infanticídio a fim de privilegiar a prevalência masculina. Daí, o controle da fecundidade imposto pelo Estado (filho único por casal) funcionar razoavelmente nas áreas urbanas, mas no meio rural permite-se um segundo filho se o primeiro não for do sexo masculino.

A despeito do excepcional crescimento da economia chinesa, há interrogações e dúvidas sobre o futuro, boa parte delas novamente referida aos recursos naturais e ao comportamento da população chinesa atualmente em processo de modernização e ocidentalização. ${ }^{1}$

De um lado, do ponto de vista econômico, surgem dúvidas e reações internacionais que denunciam em seu capitalismo predatório: a existência de subsídios internos inaceitáveis; o uso de poder econômico e militar em disputas comerciais; e a especulação nos mercados imobiliários e de commodities, no momento em que o valor do dólar se debilita e as taxas de juros internacionais estão próximas de zero. As desconfianças em relação à China e aos países da Ásia são muitas e envolvem direitos de propriedades, contratos, acordos e normas do comércio mundial. O que dizer do barateamento de seus produtos mediante desvalorização artificial do Yuan num mundo "supostamente" de câmbio flutuante? Recente declaração do ministro brasileiro Guido Mântega, com repercussão na mídia internacional, observou que o mundo vive hoje uma guerra cambial não declarada. ${ }^{2}$

Como vem noticiando a mídia nacional e internacional, também Juan Chingo, ao analisar o "grande salto para frente" da China pós Mao Tse-Tung, alerta para o surgimento de enormes desigualdades sociais, corrupção, nepotismo, inflação, novos impostos, ineficiências no funcionalismo e um pragmatismo econômico de Estado que almeja tornar, a todo custo, o país uma liderança mundial. $\mathrm{O}$ autor exagera, entretanto, ao desenhar o futuro chinês submetido aos imperativos do lucro fácil das grandes corporações transnacionais, o que tenderia a empurrar a China para o atraso tecnológico em direção à condição de semicolônia. Fatos recentes amplamente noticiados derivados da crise internacional de 2008 indicam recuperação do crescimento do PIB baseado no consumo interno e em avanços científicos e tecnológicos. Essas evidências desmentem o prognóstico sombrio de Juan Chingo.

De outro lado, questões mais básicas desafiam os analistas. Estas dizem respeito novamente aos recursos naturais e à população. Por exemplo: uma série de consequências derivadas da exacerbada exploração

\footnotetext{
1 Notícias sobre a China são divulgadas quase todos os dias em jornais do mundo inteiro. Alguns dos dados aqui apresentados foram extraídos de sites de empresas públicas e privadas, revistas, jornais, documentários televisivos, de várias edições do jornal Folha de S.Paulo e do artigo "Mitos e realidade da China atual", de Juan Chingo (2004), disponível na web.

2 No 7 ํㅜ Fórum de Economia da Fundação Getúlio Vargas (FGV), o economista Giannetti da Fonseca cunhou a expressão "massacre chinês", noção alusiva ao comércio chinês que enfeixaria contrabando, pirataria, práticas de dumping e fraudes na origem dos produtos ao utilizar terceiros como exportadores.
} 
desses recursos, degradação do meio ambiente, desperdício e efeitos nocivos sobre o equilíbrio homem-natureza desperta dúvidas, inclusive na burocracia do Estado chinês. Apesar de ser impressionante o atual gasto de água potável, as previsões parecem catastróficas diante da duplicação da produção industrial, da expansão das cidades e do aumento do consumo da população. Se é verdade que a China tornou-se líder mundial na produção de alimentos e sua agricultura já mecanizada responde pela maior produção internacional de arroz e milho, suas terras agricultáveis beiram ao esgotamento e penalizam o campesinato.

$\mathrm{O}$ antigo sistema familiar volta a viver crise séria na atualidade,$^{3}$ por força da emigração de jovens para as cidades e pelos efeitos que a modernização e urbanização têm provocado na vida rural (poluição do ar, degradação de aquíferos, desmatamento, desertificação, erosão e perda de solo). As primeiras reformas de Deng Xiaoping não conseguiram elevar a renda e a produtividade no campo, o que provocou aprofundamento das reformas subsequentes com a flexibilização da legislação fundiária, introdução de direitos de comercialização e entrada na OMC. Tais medidas acarretaram a expulsão de milhões de trabalhadores excedentes da agricultura em uma migração campo-cidade sem precedentes. De outra parte, estimativas apontam que, nos últimos 20 anos, em decorrência da desertificação e uso intensivo da terra, houve perda de 14 milhões de hectares de solo cultivável, o que tem afetado a oferta de arroz, principal item da dieta alimentar do país, secularmente plantado nas amplas planícies do Yang-tzé, onde sempre houve abundância de água e população.

Diante das metas de continuar crescendo a taxas próximas dos $9 \%$ ao ano nas próximas três décadas, isso representaria um incremento da participação chinesa no comércio mundial dos atuais $12 \%$ para algo em torno de $70 \%$. Se hoje a China detém cerca de $20 \%$ da população mundial e produz $12 \%$ do PIB mundial, as projeções indicam que, em 2040 , o país responderia por $17 \%$ da população e $70 \%$ do PIB mundial, o que implicaria declínio econômico do resto do mundo. Mas as evidências de aquecimento global e o comprometimento de recursos naturais como água, solos férteis, minérios e combustíveis fósseis permitirão a realização de cenários tão favoráveis ao país? Como saída das dificuldades que se anunciam, um novo tipo de colonialismo estaria sendo incentivado pelos dirigentes chineses, como sugerem alguns analistas? ${ }^{4}$

\section{População e recursos: uma discussão que insiste em não desaparecer}

É bastante antiga a reflexão e teorização sobre população e recursos, notadamente a partir das teses pessimistas de Malthus (1983) em fins de do século XVIII. A essência dessa teoria relativamente simples que impressionou o mundo fundamenta-se em dois pilares bastante aceitáveis na Inglaterra à época: o da imperiosidade das leis naturais e o da moral cristã. $\mathrm{O}$ primeiro

\footnotetext{
${ }^{3}$ Normas culturais milenares da vida familiar chinesa vêm alterando-se desde antes da ocupação japonesa na $2^{\text {a }}$ Guerra Mundial e aceleraram-se com a guerra civil que contrapôs os comunistas e o Kuomintang até a vitória de Mao Tse-Tung em 1949. A situação do campesinato e da mulher passou a ser valorizada até 1957. A partir daí a política econômica de produção de aço e a nova reforma agrária levaram o país ao desastre, tendo provocado a morte por fome de cerca de 30 milhões de pessoas. Um pouco depois, a Revolução Cultural iniciada em 1965 e o culto a Mao se encarregaram de dilacerar a sociedade chinesa, com a perseguição a intelectuais, artistas e milhares de famílias nas áreas urbanas. Com Deng Xiaoping a economia e o tecido social chinês se recompuseram, mas ainda hoje subsistem no meio rural antigas práticas (toleradas pelo partido comunista) que deprimem a condição feminina, tecem redes de dependência interfamiliares, em que o nepotismo e a corrupção, práticas antigas da velha China, são encontrados. Ver Chang (1996).

${ }^{4}$ Reportagem do jornal espanhol El Pais intitulava-se, segundo Folha de S.Paulo de 23/11/2020, "China coloniza América Latina". Vinícios Torres Freire, em sua coluna da Folha de S.Paulo de 1/9/2010, observa que a China foi o centro de debates no 4 으órum da FGV, sendo acusada de possuir ambições imperiais. Delfim Neto, nessa mesma edição do jornal, assinalava que o crescimento chinês não cabe em seu território e que, a despeito das vantagens do comércio Brasil e China, conviria prestar atenção nas "orientações pragmáticas dos dirigentes chineses no item compra de recursos naturais em Estados soberanos".
} 
rege a reprodução humana e o segundo coíbe "vícios" e práticas condenáveis como o aborto e o infanticídio. A natureza leva a natalidade ao máximo biológico, tendência tida como inelutável. Mas, qual seria o limite da reprodução humana? A partir do que se observava nos EUA, Malthus concluiu que o tempo de duplicação da população estava se situando em torno de 25 anos. A moral cristã-anglicana, por sua vez, consagrava o casamento, a família, o trabalho e a previdência e condenava a interrupção artificial da gravidez.

Com base nesses fundamentos, o autor construiu sua teoria, a primeira teoria de população dotada de lógica interna consistente, a despeito das críticas e limitações. Seu modelo original contrapunha o crescimento da população com os limites da produção de alimentos. A população se multiplicava em tempo curto, como em uma progressão geométrica, e os alimentos evoluíam mais lentamente, como em uma progressão aritmética. $\mathrm{O}$ alimento dependia da disponibilidade de terra agricultável, um recurso escasso limitado. A população, em sua trajetória de crescimento exponencial, acabaria sendo barrada pela impossibilidade intrínseca de a terra responder continuamente pela produção de alimentos. Os chamados checks positivos soariam como uma das formas de restaurar "naturalmente" o equilíbrio, ou seja, a fome, as epidemias e as guerras seriam uma resultante do crescimento excessivo da população, a operar como uma armadilha sempre presente na história da população mundial. Já os checks preventivos, pouco trabalhados na versão original da publicação de 1798, atuam noutra direção: alteram o imperativo biológico, seja por meio da anticoncepção e aborto, práticas pecaminosas inaceitáveis, seja pelo retardo da idade do casamento ou celibato. Se contra as forças da natureza não se pode lutar, para se contrapor à atração sexual e ao instinto de sobrevivência só restariam a prudência e a virtude como ideário recomendável, já que a procriação fora do casamento é condenada. Isso significava que mais racional e desejável para a sociedade seria adiar a idade do casamento, já que o celibato se afigurava como uma opção não generalizável. ${ }^{5}$

Malthus pautou suas convicções baseadas nesse arranjo teórico-conceitual. Suas incursões na relação capital-trabalho são conhecidas e suscitaram reações negativas de toda a esquerda mundial em face da associação evidente que fazia entre os meios de subsistência e o equilíbrio dos salários dos trabalhadores. Daí a conclusão de que salários acima do mínimo de subsistência estimulariam o aumento da população, o que forçaria, mais tarde, a redução salarial dado o excesso de mão de obra. Instalava-se uma espécie de circuito vicioso contra o qual nada se poderia fazer diante das leis da natureza, da força da paixão entre os sexos, da busca pelo prazer, entre outras realidades.

Aferrado a essa lógica, Malthus acabou assumindo postura conservadora ao defender o fim da ajuda aos pobres e a não concessão de créditos para construção de casas populares para os trabalhadores. Tais posições foram assumidas publicamente, pois ele acreditava que essas ajudas levariam ao aumento da reprodução, o que redundaria em miséria mais à frente. Curiosamente, sem que soubesse, Malthus estava inaugurando uma das bases do pensamento liberal, vivo até hoje e ainda contrário à ideia de concessões de recursos financeiros aos pobres.

$\mathrm{Na}$ maturidade, Malhtus reconheceu a importância e pertinácia dos checks preventivos em relação aos checks positivos como freio ao crescimento demográfico, provavelmente porque associavam-se ao controle moral e adequavam-se ao estilo

\footnotetext{
${ }^{5}$ Embora Malthus seja considerado pioneiro na discussão população e recursos alimentares, antes dele outros já haviam tratado do tema de forma não catastrófica. Condorcet, pensador iluminista e matemático francês, explorou a hipótese de o excessivo crescimento populacional comprometer os meios de subsistência e reduzir a felicidade humana. Condorcet, entretanto, em oposição diametral a Malthus, apostava na razão humana e no controle espontâneo da fecundidade mediante educação das massas e, principalmente, das mulheres, no que acertou magistralmente. Ver Alves (2002).
} 
de desenvolvimento econômico que se anunciava à época. Mas a velha pergunta o atormentava: restrições morais são capazes de conter a libido, obstar a imensa paixão entre os sexos e o excessivo crescimento demográfico?

De lá para cá foram muitos os estudos e achados sobre o tema, como os de Hajnal, Laslett, Macfarlane, Caldwell, Boserup, Coale, entre outros. Hajnal e Laslett examinaram as particularidades do padrão europeu do casamento e o papel exercido pela instituição dos servants (própria da Europa dos séc. XVI e XVII) como mecanismo de autorregulação populacional. Os jovens tinham que aguardar a aquisição de condições econômicas necessárias à constituição de uma família. Demonstrou-se a excepcionalidade do casamento precoce à época: a família média era relativamente pequena, 4,75 pessoas por domicílio na Inglaterra desde final do séc. XVI. Outros autores mostraram restrições ao casamento precoce, apontando itens como dote, herança, renda e propriedade, subjacentes à formação de um novo domicílio. 6

Alan Macfarlane, rediscutindo a questão, via a natalidade como uma chave da questão, ao perceber que um aumento no valor econômico dos filhos e menores restrições ao casamento dos servants poderiam ter feito baixar a idade média de casamento. $O$ autor conclui, após revisar diversas contribuições, que o padrão de casamento inglês, baseado na escolha individual, compunha-se de uma série de fatores interligados, sendo o mais importante a idade flutuante ao casar. Assim, em momento de restrições econômicas derivadas do crescimento po- pulacional, essa idade aumentava, enquanto em outros períodos em que se impunha a necessidade de mão de obra a idade diminuía (MACFARLANE, 1989).

Tamanho da família em varias sociedades, na ausência de fortes transformações econômicas, não seria uma mera decorrência de leis naturais e mecanismos de equilíbrio homoestático, como acreditava Malthus. Há razões pessoais, sociais e fisiológicas, inclusive não-econômicas, que regulam a reprodução e isso difere em cada sociedade, como nos diz Caldwell ao assinalar que em sociedades, sob diferentes estágios de desenvolvimento, o comportamento reprodutivo é absolutamente racional e a fecundidade pode ser alta ou baixa como resultado de benefícios sociais e econômicos, associados ao que chama de fluxo intergeracional de riqueza. A ideia de que alta fecundidade tipifica sociedades atrasadas, movidas pelo "máximo biológico", é contestada por Caldwell, porquanto todas as sociedades são economicamente racionais, dentro de sua estrutura de finalidades sociais. Assim, podem ser apontados dois tipos de regimes de fecundidade: um em que os indivíduos não têm ganhos econômicos em restringir a fecundidade; e outro em que ocorre o oposto. ${ }^{7}$

Ester Boserup (1987), ao estudar a evolução agrária e pressão demográfica, aprofundou várias questões deixadas em aberto pelo catastrofismo malthusiano, especialmente nos capítulos em que se debruçou sobre a dinâmica do uso da terra, a interdependência entre uso e mudança técnica, crescimento populacional e oferta de trabalho. A autora observa que no início

\footnotetext{
6 Sobre dinâmica demográfica e fecundidade em sociedades pré-industriais ver, entre outros: Wrigley (1996),Caldwell (1982), Hajnal (1982), Laslett (1974), Macfarlane (1990), Bideau (1984) e Paiva (1987).

7 Vários estudos mostram casos de tentativas bem ou malsucedidas no controle da fecundidade. No Peru, Irlanda e mesmo na China, essas tentativas baseadas apenas no cálculo econômico fracassaram em alguma medida por negligenciarem aspectos culturais, como patriarcado machista, presença da Igreja, ajuda dos filhos na velhice e estilo de vida do campesinato. Mas em Bali o planejamento familiar foi bem-sucedido. A fecundidade caiu entre 1960 e 1970 de 5,7 para 4,0 filhos por mulher. A administração comunista revelou competência na implantação dos serviços de controle da natalidade e a aceitação popular traduzia a não existência de interesses conflitivos entre o poder e a população. Já em Bangladesh, região de alta fecundidade rural, submetida a programa de planejamento familiar, não houve indícios de redução da fecundidade. Lá, a racionalidade do tamanho grande de família associava-se à estrutura de clãs, na qual a influência e domínio político das elites locais sempre foram decisivos. Os filhos constituíam claramente um valor econômico e de amparo aos idosos. Ver McNicool (1980) e O'Reilly (1986).
} 
de um processo de desenvolvimento econômico o crescimento demográfico é uma pré-condição, o que deixa os povos de população pequena e esparsa agrilhoados pela agricultura de subsistência, sem chances de alcançar níveis elevados de desenvolvimento técnico e cultural. Isso porque os aumentos da densidade populacional viabilizam incrementos de produtividade na agricultura, em razão de uma divisão de trabalho mais sofisticada, melhor educação, administração e gestão pública. Assim, uma população agrícola numerosa pode sustentar uma população também numerosa que não pratica agricultura. ${ }^{8}$

A relação homem-natureza é primordial na dinâmica demográfica, sobretudo em sociedades pré-industriais. População e recursos naturais guardam vínculos associativos decisivos para o entendimento das trajetórias da mortalidade, natalidade e migrações, e isso afeta o crescimento demográfico, mas não como formulados na proposição teórica malthusiana. Populações humanas não se reproduzem em direção ao máximo biológico exaurindo recursos de subsistência como pensavam Malthus e os neomalthusianos.

Os dois pressupostos malthusianos, o da natureza e o da religião, são insustentáveis cientificamente. $\mathrm{O}$ primeiro, a despeito da força da libido entre jovens na puberdade, ignora a racionalidade e a cultura como atributos da natureza humana. O segundo, o da moral cristã anglicana (que proíbe "vícios", aborto e infanticídio), não se sustenta teoricamente como queria o jovem e ingênuo Malthus em 1798. Teorias que se pretendam científicas geralmente dispensam a mediação da religião, como demonstraram os gregos na invenção da filosofia e da ciência. Assim, trata-se de um pressuposto eurocêntrico e tendencioso ao menosprezar a existência de sociedades distantes da influência dos três monoteísmos da Ásia Menor (judaísmo, cristianismo e islamismo).

Mesmo maduro, quando Malthus passara a defender o casamento tardio, o pessimismo, o naturalismo fatalista e o moralismo religioso impediam-no de ver que seus checks preventivos podiam ser praticados em vários tipos de sociedade. Na verdade, o fundamento da racionalidade sempre esteve presente na vida dos grupos humanos mais primitivos, daí a pertinácia das afirmações de Caldwell quando demonstrou a racionalidade pró-natalista das sociedades primitivas e tradicionais de famílias estendidas: um filho a mais era bem-vindo, pois geralmente representava um benefício e não um custo como nas sociedades urbano-industriais. ${ }^{9}$

Coale (1980) é enfático ao afirmar que não há um único exemplo histórico, em qualquer região moderna ou tradicional, cuja fecundidade se aproxime do máximo biológico. De outra parte, há suficientes evidências a demonstrar que a maioria das sociedades, sempre que necessário, controlou a fecundidade, por meio dos mais diferentes métodos. $\mathrm{O}$ autor rechaça as formulações teóricas que apregoam um caminho único e inexorável para a humanidade e discorda das teses de controle da natalidade de países de renda baixa, conforme propunham os neomalthusianos na segunda metade do século XX.

Os neomalthusianos ganharam evidência nos anos 1960, re-elaborando a teoria de Malthus sob nova roupagem. Um dos expoentes dessa corrente é o biólogo Paul Ehrlich, que publicou, em 1968, seu famoso The population bomb. Suas preocupações já não eram com a mera falta de alimentos, mas sim com o desmatamento, redução da

\footnotetext{
8 Boserup, sensível às imposições interpostas à dinâmica demográfica pela concentração de população em áreas urbanas, percebe a importância de um "um certo nível crítico de densidade populacional", sem o que não se instala uma grande cidade, um sistema de transportes, nem há a absorção de excedentes da força de trabalho e maior diversificação da economia. Citando Henri Pirenne, a autora afirma que a expansão da urbanização apoiou-se no aumento geral da população resultante da pacificação da região, após séculos de guerras e instabilidades internas e externas. A expansão demográfica nessa época se fez sem incrementos notáveis na produtividade agrícola, provavelmente ainda baseada no pousio curto e na disponibilidade de novas terras antes ocupadas por florestas (BOSERUP, 1987, p. 23-28).

9 Sobre a influência da cultura e instituições na dinâmica da fecundidade, ver Stamm e Tsui (1986), McNicool (1980), Potter (1983) e Ben-Porath (1980).
} 
biodiversidade nas áreas tropicais, efeito estufa, destruição da camada de ozônio. Com isso ele reuniu inúmeros adeptos no mundo inteiro, encorajou governos e organizações não governamentais a atuarem na promoção da contracepção em países pobres, tidos como os principais responsáveis pelo aumento demográfico, porque estariam acrescentando ao planeta um bilhão de habitantes a cada $11 / 12$ anos. O catastrofismo ganhava o mundo. Se o crescimento não fosse contido, a natureza incumbir-se-ia de fazê-lo por meio da escassez de terras, insuficiência de alimentos, fome, enfermidades, mortes e guerras.

Ehrlich, embora não traga estatísticas confiáveis em suas previsões, insiste em argumentar, ainda hoje, a favor de suas teses, arrolando novos argumentos associados à fragilização imunológica, sobretudo em grandes cidades precárias de países pobres, onde proliferam velhas e novas patologias em contextos de poluição de mananciais e crise mundial de alimentos. Nesse cenário, convulsões sociais, epidemias, violência e colapso dos serviços públicos são o que se espera nas áreas de "explosão demográfica".

Assim, um vasto programa internacional de controle da natalidade seria a solução preconizada, quiçá para reduzir a população mundial de sete para dois bilhões de indivíduos, número ideal para o biólogo. Em suas últimas asserções, Ehrlich estabeleceu uma equação em que o impacto ambiental (I), depende diretamente de $P$ (população), $C$ (consumo per capita) e $T$ (tecnologia disponível). Ao trazer o caso chinês como exemplo, o biólogo conclui que nesse país o termo $P$ está sobre controle porque a fecundidade declinou para algo em torno de 1,2\% ao ano desde 1970, $T$ vem progredindo, mas o consumo $C$ é ameaçador por causa do enorme dispêndio de água que o crescimento econômico promove. Obstinado, o autor parece impermeável a críticas e não percebe o "simplismo" de sua equação ao ignorar completamente as estruturas de poder existentes na geopolítica mundial.

Não há dúvidas de que a celeuma provocada por Ehrlich despertou a atenção de governos e organismos internacionais. $\mathrm{Na}$ época, a Divisão de População da ONU chegou a prever que a população mundial chegaria hoje a mais de 12 bilhões de habitantes, em vez dos atuais sete bilhões. Após sucessivas revisões e depois de constatar que a fecundidade declinou em todas as regiões do mundo (em torno de 2,6 filhos por mulher nas regiões pobres e menos de 1,5 filho por mulher nas regiões desenvolvidas), estimativas da ONU sugerem que, em 2050, talvez sejamos nove bilhões de pessoas no planeta. Essa diferença chega a impressionar e suscita a questão: se a bomba populacional não foi deflagrada, para onde foram os bilhões de seres humanos sobrestimados?

Os adeptos de Ehrlich insistem em dizer que isso se explica pelas imensas perdas por mortalidade infantil, Aids, malária, sarampo, diarreia na África e América Latina e abortos de bebês do sexo feminino na China e Índia. Dessa forma, eles tendem a minimizar ou duvidar dos impactos da redução voluntária do número de filhos pelas famílias, dos efeitos da urbanização na relação custo-benefício dos filhos, dos novos papéis da mulher escolarizada e do uso de diversos métodos contraceptivos modernos.

Cinco países da Ásia e um da África, boa parte deles muçulmanos, respondem por metade do crescimento mundial em termos absolutos: Índia, China, Indonésia, Paquistão, Bangladesh e Nigéria. Mas esse quadro pode estar se alterando mais rápido do que preveem os mais céticos. Mesmo com taxas superiores ao nível de reposição, começa a desabar o mito da sobrenatalidade muçulmana, especialmente nos países onde os efeitos da modernização e ocidentalização alcançam as mulheres, tais como Egito, Jordânia, Tunísia, Irã, entre outros.

\section{Aportes conceituais para uma nova formulação teórica}

Diante das múltiplas questões associadas aos processos atuais derivados da globalização econômico-financeira e do comércio internacional, coexistem práticas novas e antigas, algumas delas suscitando correlações simples e complexas entre demografia 
e economia. Discernir alguns pontos que dizem respeito à dinâmica demográfica é sempre uma tarefa desafiadora, porque envolve um antigo debate que há muito tempo se interpõe nas ciências sociais.

Inicialmente, cumpre salientar que as reflexões que se seguem não se ocupam em discutir teses liberais e neoliberais que exponenciam o livre mercado, arranjos institucionais da alta finança, capacidade de autor-replicação de processos virtuosos de produção de inovações tecnológicas. Tampouco nos propomos a discutir teses marxistas que sobre-elevam as determinações exógenas dadas pela dinâmica multiescalar do grande capital, acirramento da luta de classes, disputas entre frações do capital internacional. Sem ignorar as teses que procuram explicar a realidade socioeconômica mundial ou regional pelas novas formas impostas pelo capital financeiro internacional e grandes corporações transnacionais, pretende-se aqui realçar fatores tratados lateralmente, quais sejam, recursos naturais, população e poder estatal, dimensões causais com alto poder explicativo de realidades atuais como a da China continental.

A tese aqui proposta é que valores histórico-culturais profundos se amalgamaram de modo complexo e indissociável, em uma espécie de combinação em tríade das estruturas de poder, recursos naturais e população. Os problemas epistemológicos existentes nessa tarefa demandam campos de conhecimento como os da economia, geografia, sociologia e cultura. Atualizá-los é tarefa de muitos estudiosos e anos de trabalho transdisciplinar. Contudo, algumas intercessões resultantes da observação e do exame da literatura podem trazer ganhos teóricos pouco explorados. Para isso convém iniciar estabelecendo um conjunto de significados básicos para os termos população, espaço e poder.

Conceitualmente, população aqui refere-se a tamanho, composição por sexo e idade, balanço entre mortes e nascimentos, padrão de reprodução e migração. Outros estudiosos das Ciências Sociais raramente conhecem os significados que as estruturas demográficas escondem, algumas delas só perceptíveis no longo prazo, a exemplo do crescimento zero, bônus demográfico e envelhecimento da população em países que já completaram a transição demográfica. Assim, as componentes que informam a dinâmica demográfica podem, em alguns momentos, explicar por si mesmas certas configurações sociais porque internalizam alguma autonomia em relação às imposições da natureza, da cultura e da economia. Afinal, homens e mulheres, famílias e clãs construíram racionalidades relativamente sólidas, fundamentais à sobrevivência do grupo, a exemplo do controle do número de filhos em ambientes de restrição alimentar, ou atitudes pró-natalista em vários momentos como efeito-compensação em face das antigas crises de mortalidade. ${ }^{10}$

A noção de recursos naturais agrega as dimensões natural e social, mas se restringe nesse estudo aos espaços que dispõem de recursos naturais de dois tipos, os de subsistência e os de proeminência. O primeiro reúne os recursos necessários à sobrevivência de grandes grupos humanos: água, clima ameno, solos férteis, fauna (inclusive animais domesticáveis de grande porte) e flora (inclusive grãos, gramíneas e florestas utilizáveis como lenha e madeira na construção). O segundo refere-se à natureza transformada, mediante manipulação, extração ou transformação de recursos "in natura" que permitem fortalecer e ampliar as condições de sobrevivência. Neles estão incluídos desde sítios geográficos bem localizados, até metais como cobre, estanho, ferro, ouro, prata, mercúrio, ou substâncias como carvão mineral, chumbo, petróleo, potássio, urânio, entre outros.

Poder, por seu turno, implica consentimento e coerção em suas modalidades política, econômica, simbólica ou religiosa,

\footnotetext{
10 Há vários textos na literatura internacional dissecando esse tema. Disponível em língua portuguesa, no livro organizado por Maria Luíza Marcílio, há os capítulos escritos por Alain Bideau e J. N. Biraben (1984) mostrando os déficits cíclicos de população motivados por doenças epidêmicas na Europa.
} 
separadas ou imbricadas, mas quase sempre ancoradas na presença do Estado. ${ }^{11} \mathrm{O}$ conceito implica mais investimento teórico do que fazemos aqui, já que vem sendo discutido desde Hobbes (1988) (meios de que a pessoa dispõe para a obtenção de futuros benefícios), Weber (imposição da vontade de alguém sobre outrem em uma dada sociedade), Foucault (relações assimétricas entre pessoas e grupos humanos), ou mesmo Galbraith (1986), com seus três tipos de poder, o condigno, o compensatório e o condicionado. O condigno associa-se a determinadas personalidades, o compensatório resulta da posse e propriedade e o condicionado origina-se da organização. $\mathrm{O}$ Estado acumulou essas três fontes de poder por meio da detenção de propriedades e ativos diversos e pela intrincada estrutura organizacional que estabeleceu.

Convém sublinhar que as relações entre recursos naturais e população são evidentes. Certamente tão antiga quanto essa associação é a que se refere aos aparatos de poder capazes de estruturar sociedades simples ou complexas em suas múltiplas e conflituosas clivagens territoriais. É nessas circunstâncias que são instituídas regras de convivência e meios de defesa do território contra ataques externos.

As três dimensões de análise supracitadas, mesmo em um estudo expedito, passam por uma breve revisão histórica que estabeleça mediações entre escalas territoriais que se superpõem: local versus global; forças do particularismo; e forças do universalismo.

Uma proposição complementar é que determinadas atitudes de pessoas, grupos sociais e instituições obedecem a uma es- pécie de inconsciente coletivo ${ }^{12}$ recôndido, cuja origem foi inculcada há muito tempo pelos mitos e história, língua e cultura. Trata-se de uma espécie de memória grandiloquente que as elites manipulam em determinados momentos, ao incorporar ideais elevados de força, guerras heroicas, pompa, discursos eloquentes que perenizam antigas narrativas e traços identitários.

$\mathrm{Na}$ base dessa tensão cultural persiste o fato de que é muito antiga a consciência dos povos sobre sua fragilidade. Quando as populações começaram a crescer e se expandir geograficamente, logo se tomou conhecimento de que alguns lugares sucumbiram depois de ter vivido tempos de apogeu. Sabia-se que doenças e pragas podiam se abater sobre um povo e dizimar milhares de pessoas. Diante da possibilidade das tragédias, era comum a ideia de que o crescimento demográfico era uma espécie de dádiva dos deuses ou um valor dos bem-sucedidos, porque viabilizava a expansão territorial mediante conquistas e colonização. Crescimento soava não apenas como uma necessidade, mas também um mecanismo de compensação diante de catástrofes provocadas por crises de mortalidades mais ou menos cíclicas. A ideia de que o crescimento demográfico fosse naturalmente desejável era, portanto, suportada pelos rudimentos da ciência inventada pelos gregos ou pela regra de ouro das sagradas escrituras ("crescei e multiplicai-vos").

Em sequência, expõem-se de forma resumida quatro grandes momentos histórico-culturais, cujas consequências estão profundamente vivas até os dias de hoje, nos quais a questão população, recursos naturais e poder alçou níveis explicativos de-

\footnotetext{
${ }^{11}$ Mesmo com a subdivisão dos três poderes das constituições republicanas - Legislativo, Judiciário e Executivo -, o Estado sempre buscou a unidade político-administrativa. A expansão de sua burocracia desde fins do século XIX o auxiliou nessa tarefa. Weber (2004), por exemplo, ao descrever seus três princípios de dominação, além da forma patriarcal (baseada na autoridade cristalizada de famílias e indivíduos cultural e historicamente relevantes) e da forma carismática (derivada de característica extraordinária do líder, em suas crenças e capacidade de convencimento mediante compensações concedidas aos subordinados), sublinha a dominação burocrática, exercida por autoridades constituídas e baseadas em normas racionais instituídas, pactuadas ou impostas.

12 Nesse caso, propositadamente, tomamos de empréstimo esse conceito da psicologia analítica de Carl Jung, por considerar adequada a sua proposição de que no homem comum agem camadas profundas relativas a imagens, símbolos e objetos do passado comum da humanidade, o que daria origem ao que chamava de arquétipos, por onde são construídos os mitos.
} 
cisivos na trajetória subsequente dos povos que protagonizaram mudanças estruturais de longa duração.

\section{Tempo 1: Expansão territorial na passagem da caça-coleta à agricultura}

Pesquisas baseadas no DNA mitocondrial revelam que o homem anatomicamente moderno, a espécie que colonizou o planeta, originou-se da África subsaariana há cerca de 200 mil anos, embora os vestígios arqueológicos mais precisos indiquem a marca dos 150 mil anos. Sua expansão mundial foi inexorável, mas difícil e arriscada em face de sua convivência no pleistoceno com glaciações e catástrofes sísmicas e ambientais de grande magnitude. Ademais, as áreas superficiais do planeta suscetíveis de serem habitadas eram menores que os 100 milhões de $\mathrm{km}^{2}$ da atualidade. Antes, nos períodos glaciares, essas áreas encolhiam-se por causa da ampliação das calotas polares, o que tornava a sobrevivência humana muito penosa em certas latitudes. As grandes migrações de grupos de caçadores-coletores na incessante busca por alimentos faziam parte desse ambiente, já que, com as glaciações, o nível dos oceanos chegava a baixar até 200 metros, o que propiciava o surgimento de inúmeras passagens terrestres, como as que permitiram a ligação da Ásia com a América, do Japão com a Indonésia, Nova Guiné e Austrália. Grande parte do processo de difusão do homo sapiens pelo planeta se fez por meio dessas pontes naturais que se desfaziam ao final de cada glaciação. Ao que tudo indica, desde mais ou menos 50 mil anos atrás ocorreu um vigoroso processo de crescimento demográfico e difusão espacial da espécie sapiens, o que tornou possível resistir ao clima da última Era Glacial, iniciada em torno de 30 mil anos atrás, cujo esgotamento só se daria mais de 15 mil anos depois, quando a população, a duras penas, teria alcançado a casa de alguns milhões de indivíduos. ${ }^{13}$

$\mathrm{O}$ advento da agricultura coincide com o Holoceno, período inusitadamente quente e de extraordinária estabilidade climática que cobre os últimos 10 mil anos, cujas condições bioclimáticas fizeram a agricultura prosperar. Mesmo em nichos ricos em biodiversidade da Ásia do Paleolítico Superior, eram limitadas as condições de vida dos caçadores de renas e mamutes. De fato, só com o Holoceno foi possível a chamada Revolução Neolítica, com o advento da agricultura e o surgimento de um conjunto de mudanças que redefiniram a trajetória humana no planeta.

Mas onde isso se deu? Se agricultura significa cultivo de vegetais e criação de animais, existiram vários lugares onde havia uma flora que alimentasse herbívoros e seres humanos? Com o gradativo recuo das geleiras, o planeta tornava-se mais quente e isso propiciou o surgimento de amplas florestas, novos tipos de arbustos e extensas áreas de gramíneas mais ricas em nutrientes. Determinados tipos de herbívoros povoavam uma grande extensão da Eurásia e em alguns vales especiais havia abundância de capins adequados à sua alimentação. Os vales dos rios Tigre, Eufrates e Jordão, o chamado Crescente Fértil, formaram uma dessas regiões privilegiadas, onde a Revolução Agrícola iniciou-se. ${ }^{14}$ Progressivamente, mas de forma independente ${ }^{15}$ sociedades agrícolas surgiram no

\footnotetext{
13 Para mais detalhes ver Breton (1990).

14 Jared Diamond (2009, p. 98) sublinha que no Crescente Fertil, há quase 11.000 anos, o trigo, a ervilha e a azeitona foram culturas fundadoras, ao lado da criação de cabras e ovelhas; na China a agricultura surgiu cerca de 9.500 anos atrás, apoiada no cultivo do arroz, milho moído, na criação de porcos e bicho da seda; na Mesoamérica, o milho, o feijão e abóboras, ao lado da criação de perus, compunham o pacote agrícola em torno de 3500 a.C.; mais ou menos na mesma época, nos Andes e Amazônia, práticas agrícolas se instalavam a partir da batata, mandioca, criação de lhamas, vicunha e porquinho da índia. O autor cita ainda o leste dos EUA como região em que o cultivo de sorgo e arroz se desenvolveu há 4.500 anos, além da Índia, Etiópia e Nova Guiné e outras regiões em que a agricultura irradiou-se mediante expansão das culturas fundadoras. Observa-se, entretanto, que em várias dessas "outras" regiões relacionadas pelo autor o crescimento populacional não chegou a estruturar sociedades densas que viriam sediar impérios poderosos, embora quase sempre os povos agrícolas submetessem ou eliminassem as comunidades de caçadores-coletores remanescentes, como no exemplo dos Maoris e Moriori na Nova Zelândia.
} 
México e áreas vizinhas da Mesoamérica no Altiplano dos Andes e bacia amazônica.

Com a progressão do degelo e o aumento da umidade e calor, as gramíneas selvagens dispersaram-se por áreas bem maiores e tornaram-se cereais: gramíneas selecionadas para cultivo humano. ${ }^{16}$ É inegável que as alterações climáticas foram um fator decisivo para o crescimento demográfico. Mesmo que ainda haja alguma controvérsia, fica difícil sustentar a tese de que a população anteriormente expandida possa ter sido a causa da revolução agrícola. Se as populações vinham aumentando ao final da última Era Glacial, pesquisas mais recentes têm deixado evidente que o novo ritmo de crescimento demográfico foi resultado do uso sistemático da agricultura. Antes, sob o regime da caça-coleta, os obstáculos ao crescimento demográfico eram muito evidentes.

[...] os caçadores-coletores nômades são extremamente limitados quanto ao que podem carregar consigo e isto se aplica às crianças tanto quanto aos bens. Além disso, as mulheres nessas sociedades não podem participar de uma expedição de coleta carregando mais de um filho, e assim os nascimentos tendem a ser espaçados para cada quatro anos, como vimos no caso dos Kung [população de caçadores-coletores da África meridional estudada pelo autor]. O controle da natalidade através de vários métodos, como a prolongada amamentação, as ervas medicinais e o infanticídio, é uma prática comum entre os grupos nômades e, como resultado, as populações permanecem relativamente constantes. Quando os caçadores-coletores se tornam sedentários, a restrição em relação aos nascimentos é suspensa e a população pode crescer (LEAKEY, 1982, p. 203).
Diversas publicações internacionais reafirmam essa evidência. A adaptação em português da edição inglesa e francesa do The times history of the word, por exemplo, é bem explícita quando afirma que os significados da sedentarização foram extraordinários e a garantia de sobrevivência ao longo do ano fez com que os "deslocamentos necessários ao sustento [se tornassem] mínimos, as limitações postas à fecundidade devido ao modo de vida dependente das estações diminuíram e a população aumentou" (ATLAS DE HISTÓRIA MUNDIAL, 2001, p. 36).

As regiões que adotaram a agricultura tornaram-se bastante populosas no Neolítico e ainda o são até hoje: a Mesopotâmia; as regiões da planície noroeste da China; o delta do Nilo; a Índia; e, independente dessas experiências, a Mesoamérica.

Três inferências analíticas podem ser relacionadas:

- o recuo das geleiras permitiu o cultivo independente de cereais de alto poder nutritivo, como trigo, arroz e milho no Oriente Próximo, Noroeste Chinês, Mesoamérica e Andes. A difusão da agricultura alcançou outras regiões, como o delta do Nilo, o Sael, a Índia, a Nova Guiné. Isso veio favorecer a superação do velho regime socioespacial de sobrevivência precária dos grupos nômades que dependiam da caça-coleta e eram forçados a conviver com baixa expectativa de vida e reduzido crescimento demográfico;

- a agricultura reúne um pacote de práticas associadas à domesticação de vegetais, criação de animais, uso e manejo do solo, o que inclui a semeadura, a seleção de espécies e a

\footnotetext{
15 Análises recentes do DNA mitocondrial e dos cromossomos Y revelam que os europeus são descendentes de populações do Paleolítico Superior que habitavam o continente. Há evidências de empréstimo cultural derivado da experiência da agricultura no Crescente Fértil, algo bem distinto da eclosão independente da agricultura na Mesoamérica, por volta de 4.000 a.C. (COOK, 2005, p. 38).

${ }^{16}$ A mudança climática alterou o meio ambiente e modificou as características de muitos vegetais. O trigo selvagem quando encontrado em largas quantidades não demoraria muito tempo para ser domesticado e se tornar um alimento básico do Oriente Próximo. Sua coleta e processamento eram simples e acessíveis. Em 1966, Jack Harlan, com uma vara de cavar de sílex de 9 mil anos de idade, fez esse exercício. Em uma hora chegou a ceifar quase $3 \mathrm{~kg}$ de trigo selvagem no interior da Turquia. Mostrou ser possível uma família coletar, em três semanas, mais grãos do que ela poderia consumir durante um ano (LEAKEY, 1982, p. 207).
} 
irrigação. O trato de grandes herbívoros domesticados e a necessidade de defesa do curral, das áreas cultivadas e das construções de armazenamento alteraram a divisão de trabalho e novos papéis sexuais emergiram com a proliferação de aldeias rurais e o surgimento do patriarcado. Esse novo ambiente social favoreceu a produção de excedentes populacionais, a revalorização do espaço-natureza como riqueza, a inovação técnica nos fornos de alta temperatura, o domínio dos metais, a produção de armamentos e de instalações hidráulicas e de defesa;

- a expansão e apropriação de novos territórios, o comércio e a emergência dos primeiros assentamentos urbanos foram alguns dos resultados desses processos que favoreceram os povos politicamente mais estruturados. A terra e os recursos de proeminência passam a ser o balizador da organização econômica e provocam o surgimento de formas duráveis de poder monárquico que dariam o sustentáculo aos futuros grandes impérios, prenúncio de um longo período de guerras de conquistas e anexações.

Biólogos e outros estudiosos estimam que a população mundial teria alcançado entre cinco e dez milhões no início do Holoceno. Oito mil anos depois, à época do nascimento de Cristo, este número teria se multiplicado muitas vezes, atingindo entre 150 e 300 milhões, um terço dessa população em torno do Mediterrâneo e outro terço na China. ${ }^{17}$

\section{Tempo 2: Espaço, população e legados culturais na época dos gregos}

Os gregos, a partir de 700 a.C., influenciados pelos fenícios, persas, minoicos e egípcios, construíram uma civilização de grande alcance histórico desde o Peloponeso e ilhas do Mar Egeu. Mesmo não possuindo uma agricultura apoiada em grandes vales fluviais, eles dominaram a tecnologia dos metais e a navegação, conheceram vários povos e terras da orla do Mediterrâneo, estabeleceram feitorias comerciais, tornaram-se hábeis na guerra e estruturaram uma forma jurisdicional de poder baseado na Cidade-estado. Tanto quantos os fenícios, também trilharam a senda da colonização.

$\mathrm{Na}$ época em que os Estados mais poderosos estavam instalados no Oriente e Oriente Próximo, os gregos inventaram a cidade dos magistrados e a ágora, lugares onde direitos civis e poder político coletivo eram exercidos com base no pensamento racional, escrita pública, direito à palavra nas assembleias, lei para todos e subordinação da religião, mas paralelamente tornaram-se extremamente equipados para a guerra e defesa de seus territórios. Criaram uma forma inédita de Estado que aplica penas em conformidade com a lei humana. Disseminaram a escola laica e a ciência a partir de Tales e Anaximandro. Fizeram avançar a matemática, a física, a astronomia, a biologia, a medicina, as ciências sociais, enquanto Platão e Aristóteles criavam a filosofia e a ciência política no período helenístico. ${ }^{18}$ Alguns estudiosos concluem que os gregos não foram mais longe, talvez porque a ciência e as técnicas que adotavam tinham um caráter amador, e, juntamente com a

\footnotetext{
17 Alguns estudos estimam que no século XVI o planeta possuía 500 milhões de pessoas. Cálculos otimistas apontam a população de um bilhão de habitantes em 1750, nas proximidades da Revolução Industrial, enquanto os menos otimistas sugerem 800 milhões. Daí em diante a população cresceu vertiginosamente, chegando a 1,6 bilhão em 1900 e 3,0 bilhões nos anos 1960. Em 01 de janeiro de 2011, o Relógio da População do Censo dos Estados Unidos calculava em 6,89 bilhões de habitantes a população mundial (http://www.eumed.net/cursecon/2/evolucion.htm). Segundo projeções da ONU, em apenas 13 anos alcançamos nosso quinto bilhão. Recentemente, entre 1980 e 1990, cerca de 923 milhões de pessoas se adicionaram à população mundial. Para mais detalhamento ver também Livi-Bacci (1992).

18 Sobre a influência do pensamento grego e romano na formação do Ocidente, ver Nemo (2005).
} 
prática arraigada da escravidão, faltava-lhes o impulso para mudar o mundo. Com isso, acabaram se esfacelando territorialmente após o curto expansionismo de Alexandre e subsequente sujeição aos romanos.

Em A voz da aldeia, Lewis Munford, a partir de sua leitura da obra de Hesíodo, defende a ideia de que a cidade egeia e suas colônias ergueram-se a partir da cultura da vida em aldeias. Nas fortalezas naturais dos vales fechados das terras do Mar Egeu, havia cereais nas planícies da Tessália e da Beócia suficientes para alimentar as antigas populações em crescimento, as quais também contavam com o pescado, disponível nas cidades próximas do mar, como Atenas e Corinto. Fortalezas naturais rodeadas de aldeias, fáceis de defender, eram sítios comuns na Ásia Menor, Sicília e Eritreia. Diante de ameaças, a população mobilizava-se rapidamente, se encarapitava nas íngremes encostas e os inimigos tinham enormes dificuldades de vencer aldeões bem organizados, favorecidos pelo quadro natural. Isso durou séculos e aí, segundo o autor, reside a origem mais remota da democracia grega. Nesse período de formação, o pequeno tamanho populacional era uma constante nas cidades e aldeias e teria favorecido a gestão democrática e o exercício da cidadania. Munford é incisivo:

As práticas democráticas da aldeia, sem fortes clivagens de classe ou vocação, incentivavam o hábito de se aconselhar em conjunto [...] Nem mesmo o crescimento do imperialismo, no quinto século, embora transformasse Atenas numa impiedosa exploradora das cidades gregas menores, trouxe a restauração da realeza, nem mesmo aumentou o domínio dos deuses olímpicos [...] Cidades com apenas alguns milhares de habitantes criavam colônias muito antes de se tornarem interiormente congestionadas. Mesmo que a cidade tivesse procurado uma população maior, os limites das terras aráveis e de um suficiente suprimento de água teriam ainda vencido o seu crescimento. Atenas, embora rodeada por um solo aluvial relativamente rico, provavelmente não abrigava mais que cem mil habitantes, inclusive escravos, no quinto século; e é duvidoso que Mileto ou Corinto, para mencionar duas prosperas capitais, pudessem ter possuído muito mais. (MUNFORD, 1965, p. 171-173).
As cidades procuravam autonomia e a colonização grega não discrepa dessa assertiva, pois foram muitas as colônias implantadas da orla do Mediterrâneo até a Ásia Menor relativamente autônomas. Marselha, Náucratis, Rodes e Mileto tornaram-se exemplos de grandes centros comerciais. É evidente que o colonialismo iria ganhar outras características e muito maior extensão territorial no período romano, embora no tempo dos gregos só Mileto teria criado 70 colônias urbanas. Atenas, outro polo colonizador, estruturou-se com base em seu vasto comércio marítimo que abarcava azeite, cerâmica, tecidos, madeira, ametista, marfim, prata, ouro e âmbar, o que exigiu a formação de uma grande força militar para assegurar suas conquistas e não interromper o fluxo de recursos e tributos provenientes de suas possessões.

Para Munford, embora a participação no comércio fosse proibida em Egina e Quios, foi nas cidades comerciais da Jônia que "todo um mundo de ideias apareceu", mas que desapareceria com a expansão imperial dos reis divinizados. As "superstições do poder voltaram com o exercício do próprio poder militar ultra-centralizado". Apoiado em Hesíodo, o autor conclui que, em decorrência da intensificação da urbanização e da circulação econômica, houve um momento em que a guerra prevaleceu sobre a paz (supostamente resultante dos debates e das soluções democráticas). Daí sua afirmativa de que o "aldeão odiava e denunciava a guerra, ao passo que era Platão, o filósofo urbano, que a elogiava como essencial para o desenvolvimento das virtudes humanas"(MUNFORD, 1965, p. 176-177).

Platão e Aristóteles, grandes filósofos de seu tempo e ícones do pensamento mundial, deixaram profundas influências sobre as civilizações cristã, judaica e árabe. Viveram em Atenas no século III a.C., estiveram juntos por 20 anos como mestre e discípulo e conheceram a história dos principais povos da época, mas inovaram ao erigir os pilares da filosofia e ciência moderna, particularmente Aristóteles com seus princípios metodológicos consagrados em vários livros.

Política, a obra-prima de Aristóteles, escrita durante muitos anos, foi e continua 
sendo uma referência obrigatória no mundo inteiro. O que o autor nos diz sobre espaço, poder e população a partir de sua observação dos assentamentos humanos mais densos da época, as Cidades-estados do Mediterrâneo?

Em seu receituário da forma ideal de vida em uma cidade independente, feliz, guiada pela moderação, pelo princípio racional e pelo bom governo, Aristóteles assevera que o território deveria ser suficientemente grande para suprir os cidadãos. Como a cidade ideal requer engenho, planejamento e governança, no livro VII, o autor deixa evidente a sua preocupação com a administração política:

primeiramente, o estadista deve considerar a multidão de homens: ele deve refletir sobre o número ideal de cidadãos e as características do território. Muitas pessoas acreditam que para que uma Cidade seja próspera, é necessário que tenha um território extenso; mas mesmo que isso seja correto [...] deveriam considerar [antes] o poder de seus habitantes. [Adverte que] a experiência demonstra que uma Cidade populosa em demasia raramente pode ser bem governada (ARISTÓTELES, 2006, p. 248-259).

É provável que nessa assertiva esteja uma das chaves do esforço colonizador dos gregos, já que se a cidade crescer muito demograficamente, a solução que pareceria "natural" seria a criação de uma nova Cidade-estado. Preocupado com uma espécie de caos urbano, o autor observa que "quando a população é muito grande, ela se estabelece territorialmente ao acaso, o que, obviamente é inapropriado [...] Então, o melhor limite populacional para uma Cidade é o encontro do número necessário para a sua autossuficiência" (ARISTÓTELES, 2006, p. 248-259)..$^{19}$ Esse espaço não pode ser facilmente penetrado por inimigos, mas deve ter fácil acessibilidade aos habitantes, à entrada de gêneros agrícolas e outros produtos de abastecimento. A cidade deve estar bem situada "tanto em relação ao mar quanto a terra" e beneficiar-se de posição central "para poder comunicar-se com todo o seu território, protegendo-o" (ARISTÓTELES, 2006, p. 210, 241-243).

É evidente que Aristóteles via a cidade grega como o ápice da civilização mundial. Embora discordasse das pretensões "imperialistas" de Alexandre, o Grande, de quem foi preceptor, aceitava de bom grado a profusão de cidades no Mediterrâneo irmanadas pela mesma língua e cultura, pelos predicados de inteligência, bravura, inventividade e liberdade da "raça helênica". Recomendava que uma cidade deve possuir uma força naval, de modo que passe a representar "uma fortaleza não apenas para os seus cidadãos, mas também ser temível e prestar socorro aos habitantes de Cidades vizinhas [prováveis colônias], e se necessário estar pronta para ajudá-los por mar e por terra" (ARISTÓTELES, 2006, p. 243-244).

\section{Sobre o excedente populacional indesejado}

No livro VII, ao examinar o sistema educacional ideal, Aristóteles trata da questão demográfica rapidamente, mas o suficiente para mostrar como se fazia o controle do crescimento da natalidade em seu tempo. Para isso, muito antes de Malthus, ele recomendava ao legislador uma forma de casamento tardio, ao tecer considerações sobre as idades e critérios de escolha dos nubentes. Observa que a lei da Cidade, ao se fundamentar nas idades da população, capacidade de procriação, proibição do adultério entre casados e na expectativa de vida de homens e mulheres, deve incentivar casamentos em que não haja infertilidade associada à idade dos cônjuges. A diferença de idade entre os casais não deve ser pequena, pois o casamento de pessoas muito jovens repercute negativamente na

\footnotetext{
${ }^{19}$ Aristóteles entendia que as terras das cidades devem ter salubridade, fartura de água potável, divididas em propriedades, embora esse não fosse o fundamento da vida na polis, já que a cidade era, antes de tudo, uma comunidade de iguais em busca da melhor vida possível. O filósofo, a despeito da importância que atribui às fortificações e à força militar, entende que a paz é a finalidade da guerra assim como o lazer é a finalidade do trabalho e o melhor tipo de governo é aquele que se exerce sobre "homens livres".
} 
educação dos filhos: filhos de pais muito jovens tendem a perder o respeito aos pais por se sentirem companheiros da mesma idade, o que gera muitas disputas no cotidiano. Já filhos de homens idosos tendem a ser frágeis e de alma defeituosa.

O filósofo sugere aos legisladores que promovam casamentos considerando certos cálculos, respeitada a tradição. Observa que:

desde que a longevidade média do homem é de setenta anos e a da mulher cinqüenta, o início da união conjugal deve ser proporcional a esses períodos. A união de um casal muito jovem é prejudicial para a procriação de crianças; no caso de todos os outros animais, as ninhadas de animais muito jovens são pequenas e mal desenvolvidas, e com uma tendência acentuada para o nascimento de fêmeas, e o mesmo se dá com os casais humanos, conforme já está provado [...] nas Cidades em que homens e mulheres estão acostumados a se casar jovens, as pessoas são franzinas e frágeis; mulheres muito jovens sofrem mais durante o parto, e um número maior de parturientes jovens falecem. (ARISTÓTELES, 2006, p. 262)

A par dessas evidências e feitas as contas, o filósofo conclui que as "mulheres deveriam casar por volta dos dezoito anos de idade, e os homens aos trinta sete; então estarão na flor da idade, e o declínio das forças sexuais de ambos irá coincidir. Ademais, se as crianças nascerem logo, como se pode esperar que aconteça, herdarão os bens de seu pai", momento em que o pai já estaria com cerca de 70 anos de idade (ARISTÓTELES, 2006, p. 262).

Mas se ainda assim a população começar a exceder aos limites da Cidade ideal, o que fazer? Livre das interdições do monoteísmo religioso que lhe sucederia, Aristóteles inadvertidamente estabeleceu uma série de orientações que foram objeto de discussão por milhares de anos e estão vivas até hoje. Atento observador da natureza e dos diferentes costumes das cidades gregas e de outros países, o filósofos diz que:

quanto à aceitação ou rejeição das crianças, terá de haver leis segundo as quais as crianças com deformidades não devem viver, todavia, quanto a um eventual excesso de nascimentos, caso os costumes da Cidade proíbam o abandono de recém-nascidos, o costume deve ser respeitado, mas quando os casais têm excesso de filhos o aborto deve ser facultado, desde que ocorra na fase de gestação em que a criança ainda não desenvolveu os sentidos e a vida. $A$ legalidade do aborto será determinada pelo critério de haver ou não a sensação e vida. (ARISTÓTELES, 2006, p. 263-264).

Ao que tudo indica, práticas de infanticídio eram comuns nas cidades gregas, como aponta Munford (1965, p. 173) ao descrever as precariedades das periferias urbanas, onde "há muitas provas a mostrar que imundícies de toda qualidade se acumulavam nas bordas da cidade; era em tais monturos municipais que os bebês indesejáveis de Atenas eram expostos e deixados à morte".

\section{Tempo 3: Europeus em busca de um novo mundo}

O terceiro tempo histórico aqui destacado refere-se à reestruturação econômica e cultural que a Europa viveu no século $\mathrm{XVI}$, com o renascimento, as grandes navegações, a reforma e contrarreforma no cristianismo e o lançamento dos pilares de uma economia de mercado mundializada. A arrancada europeia em direção à incorporação de novas terras não é fruto apenas da tomada de Constantinopla pelos turcos otomanos em 1453, mas associa-se a uma série de fatores entre os quais cabe mencionar a nova geopolítica que potencializa regiões dinâmicas e aguerridas, como Gênova, Veneza, Portugal, Espanha e países baixos. Sem esses novos protagonismos fica difícil explicar a passagem da Europa da condição periférica do mundo civilizado eurasiano à de área hegemônica nos séculos seguintes.

$\mathrm{Na}$ época, a China já possuía mais de 100 milhões de habitantes, explorava seus recursos naturais e possuía um vigoroso comércio, enquanto Constantinopla, a maior cidade do mundo, sediava o poderoso Império Otomano que se expandia no norte da África. O que afinal ocorreu com a Europa a ponto de torná-la uma grande força mundial? Dentre tantos fatores explicativos, pode-se sinteticamente mencionar pelo menos três. 
Em primeiro lugar, cabe sublinhar o grupo de cidades dinâmicas, que iriam sediar as economias-mundo, como propõe Fernand Braudel. Em pouco tempo são forjados os fundamentos da supremacia mundial europeia. 20 As Grandes Navegações, desde o pioneirismo português munido de suas caravelas e armadas, impactaram a Europa Ocidental porque introduziram um formidável processo de redistribuição dos ganhos econômicos decorrente da difusão de novas mercadorias, metais, gêneros agrícolas, escravos, armamentos e navios, além de inaugurar um processo de exploração colonial, sobretudo na América, sem precedentes na história mundial. Se a população vinha se expandindo, como na Espanha e Portugal do século XV, ${ }^{21}$ a conjunção de todas as mudanças postas em marcha explica a continuidade do crescimento demográfico subsequente entre 1500 e 1800. Novas culturas e inovações na agricultura repercutiram econômica e demograficamente no continente apoiadas em produtos como arroz, batata, frutas, pescado, açúcar, algodão, além das especiarias.

Um segundo ponto a destacar diz respeito ao dinamismo do noroeste europeu. De fato, o poder econômico dos ibéricos não durou muito tempo. Os portugueses encontravam dificuldades em sustentar a Carreira das Índias. E os espanhóis foram inaptos no uso da prata americana, que não alterou estruturalmente sua economia: em meio ao aumento da capacidade de compra, disseminaram-se o fundamentalismo clerical improdutivo, o parasitismo, a especulação, inflação e guerras. Simultaneamente, no no- roeste europeu surgia uma nova economia na Holanda, sob Felipe o Bom, e na Inglaterra, com Henrique VII. ${ }^{22}$ Nesses países a atividade comercial e industrial superava a agricultura e políticas protecionistas eram assumidas por um novo tipo de Estado que priorizava o interesse mercantil apoiado pelas armas e pela reorganização do poder estatal. Antuérpia e Amsterdã tornaram-se centros econômicos financeiros e centralizaram a extraordinária expansão mundial da Holanda, enquanto a Inglaterra promovia reformas que pavimentariam o caminho de sua arrancada econômica subsequente.

A reforma anglicana, elemento formador do capitalismo inglês, é objeto de discussão desde Max Weber, por seu conteúdo econômico evidente em face da expropriação e redistribuição das terras da Igreja, juntamente com a difusão de uma nova cultura que valorizava o lucro e conforto material obtidos pelo trabalhador ou comerciante ordeiro, sóbrio, merecedor da graça divina. Sob Calvino, Lutero e Henrique VIII, todo o noroeste europeu é sacudido pelas novas ideias, o que iria consolidar o poder da burguesia emergente e do Estado nacionalista.

A despeito dos esforços do papa na contrarreforma a partir do Concílio de Trento (1545-63), no momento em que os conflitos religiosos fraturavam o continente, a Europa enriquecia. Uma série de novos produtos circulava no continente, inovações técnicas atingiam a metalurgia, a navegação e a fabricação de armas, enquanto expandiam-se o crédito, as bolsas, os seguros, a organização bancária e financeira. Cresciam as cidades, as populações e os mercados. Alterava-se a fisionomia rural com os "cercamentos" e

\footnotetext{
20 Sobre esse período ver Dobb (1973), Hobsbawn (1997), Braudel (1995-1996), Wallerstein (1998) e Arrighi (1996).

21 Para mais detalhes ver Pirrene (1978) e Ramos (2004).

22 Sobre a formação do capitalismo mundial, a contribuição de Wallerstein é significativa, embora pouco alicerçada na reconfiguração estatal das estruturas de poder. Na origem de suas formulações sobre sistemas históricos complexos, comparecem as influências de Marx (dominância histórica da dinâmica econômica sobre fatores políticos e culturais subsumidos pela dicotomia capital e trabalho); de Fernand Braudel (redes econômicas poderosas formando regiões prósperas e nucleando uma sucessão de Economias-mundo); e de Max Weber (com suas teses sobre a evolução da política, instituições na constituição dos Estados modernos). Wallerstein esforça-se em dar visibilidade às realidades têmporo-espaciais e procura respostas ao atraso de regiões subdesenvolvidas. O sistema-mundo é complexo, de equilíbrio precário, dadas as fricções internas resultantes do imperativo da acumulação, que convive com desigualdades de poder econômico derivadas da concentração e controle de determinados monopólios produtivos rentáveis, recursos estratégicos, infraestruturas, tecnologia e trabalho (WALLERSTEIN, 1974).
} 
o forte incremento da agricultura comercial. Os pobres se amontoavam nas cidades inglesas e a ordem feudal cambaleava. ${ }^{23}$

Um terceiro aspecto não menos importante refere-se às mudanças culturais. Novas mentalidades gradativamente alteraram a forma de pensar e agir até alcançar, com o tempo, boa parte da população europeia. Essas mudanças enfeixavam o ideal neoplatônico, o universo de Copérnico, as teses racionalistas, o renascimento italiano, as novas expressões artísticas, o individualismo, além da crítica ao despudor da Igreja. A disseminação do cisma religioso foi capaz de romper as bases do catolicismo e fazer emergir o protestantismo.

Nesse ambiente surgem novas teorias e correntes artísticas e filosóficas que marcaram profundamente o futuro do Ocidente. Nomes como Galileu, Newton, Giordano Bruno, Descartes, Espinosa, Francis Bacon, Leonardo da Vinci, Michelangelo, Maquiavel e Tomas Morus deixaram um legado de ideias e realizações.

\section{Maquiavel e Morus: uma atualização do pensamento de Aristóteles e Platão}

O italiano Nicolau Maquiavel (14691527) e o inglês Tomás Morus (1478-1535) viveram na mesma época, embora provavelmente não tivessem se comunicado. Ambos desempenharam funções importantes em seus países, estavam impregnados do humanismo e do ambiente de mudanças que varriam a Europa. A influência de seus livros foi muito mais longe no tempo do que podiam imaginar. Tomás Morus, um dos maiores pensadores de seu tempo, foi lido e cultuado no mundo inteiro, venerado na Rússia soviética. Em vida lutou pelos ideais do catolicismo, embora tenha se inspirado em ideias e princípios filosóficos pré-cristãos contidos em seu livro de preferência, $A R e$ pública, de Platão.

Já Maquiavel, ao escrever O príncipe, desejava uma Itália unida e poderosa, liderada por um monarca de pulso firme. Como renascentista, prezava muito as ideias de Aristóteles e enaltecia a arte de governar sem hesitações: "sou de parecer de que é melhor ser ousado do que prudente". Era pragmático e priorizava as razões de um Estado laico. Ao assistir a formação de Estados na Europa renascentista, Maquiavel enxergava os jogos de astúcia, virtude e ambição entre os que detêm poder. No capítulo 3 o autor é bem explicito ao abordar os principados novos, recomendando que "um dos maiores e mais eficientes remédios seria aquele do conquistador [de um território] ir habitá-los. Isto tornaria mais segura e mais duradoura a posse adquirida", porque reprimira as desordens em seu nascedouro. Instalar colônias era "outro remédio eficaz".

Nas conquistas de Estados mais consolidados, Maquiavel diz (no capítulo 5) que, se não for possível arruiná-los, pode-se "deixá-los viver com suas leis, arrecadando um tributo e criando em seu interior um governo de poucos, que se conservam amigos". Afinal, o conquistador "de uma cidade acostumada a viver livre" se não a destruir pode "ser destruído por ela, porque [nas rebeliões], o nome da liberdade e o de suas antigas instituições" nunca são esquecidos. No capítulo 8 , ele constrói um verdadeiro princípio de poder político, utilizado até hoje por governos autoritários: convém no início do governo "exercer todas aquelas ofensas que se lhe tornem necessárias, fazendo-as todas a um tempo só para não precisar renová-las a cada dia e poder, assim, dar segurança aos homens e conquistá-los com benefícios".

Observador atento de seu tempo, Maquiavel percebia as diferenças entre as monarquias e sabia dos riscos subjacentes em determinadas guerras de conquista. Era essencial estar preparado para a guerra, o que requeria uma organização militar disciplinada, treinada e conhecedora da geografia e história dos territórios em disputa. No capítulo 14, o autor anota que a guerra é "a única arte que compete a quem comanda [...] quando os príncipes pensam mais nas

23 Ver Dobb (1973), Hobsbawn (1997) e Braudel (1995-1996). 
delicadezas do que nas armas, perdem o seu Estado". O príncipe deve:

manter bem organizadas e exercitadas as suas tropas, deve estar sempre em caçadas para acostumar o corpo às fadigas e, em parte, para conhecer a natureza dos lugares e saber como surgem os montes, como embocam os vales, como se estendem as planícies, e aprender a natureza dos rios e dos pântanos, pondo muita atenção em tudo isso.

Tomas Mórus, por sua vez, no seu tratado sobre a melhor forma de governo, no mundo ideal da ilha de Utopia, pontua uma série de princípios e normas que regulariam de forma racional e organizada a vida no campo e nas cidades. A ilha estruturada por uma rede de 54 cidades "idênticas pela língua, os costumes, as instituições e as leis" (MORUS, 1997, p. 71) tinha seu fundamento econômico na agricultura, a atividade comum a todos habitantes. Assim, também as famílias que residiam nas cidades deviam dedicar anualmente parte de seu trabalho à lavoura, a despeito de cada família agrícola contar ainda com até "dois servos ligados à gleba". Tal como na Europa feudal, as cidades eram monárquicas, muradas, protegidas contra ameaças externas. O príncipe de Utopia possui mandato vitalício, desde que não se torne um tirano.

Os costumes e hábitos familiares são rígidos e obedecem a um planejamento prévio que controla o tamanho das cidades, bairros e das famílias. Cultivavam-se a natureza, virtude, arte, festas e cultos religiosos, mas havia formas patriarcais de controle social, tal qual nas antigas comunidades agrícolas europeias de famílias estendidas, porquanto as mulheres, "quando núbeis, são dadas em casamento e vão viver na família de seu marido, enquanto os filhos e os netos permanecem na família e obedecem ao mais idoso dos chefes" (MORUS, 1997, p. 86). Além disso, uma moça não se casa antes dos 22 anos e um rapaz antes dos 26 e amores clandestinos eram severamente punidos. Na construção teórica moralista-religiosa de Malthus também se combatem "vícios" e estimulam-se as "virtudes" supostamente existentes no casamento responsável realizado em idade "ideal", como meio de reduzir a natalidade.

Como os filósofos gregos, o ideal era equilibrar população e recursos naturais circundantes. As cidades de Mórus deviam ter um número mínimo de habitantes, incluindo os escravos, e não poderiam ser superpovoadas, embora o número de filhos não pudesse ser limitado. A solução implicava expansão territorial e colonização. Diante da necessidade de mais espaços em Utopia, os cidadãos buscavam ocupar terras deixadas "incultas pelos indígenas". Se os nativos se recusassem a integrar ao sistema social de Utopia, os utopianos "os expulsam do território que escolheram e lutam de armas na mão contra os que resistirem. Pois [a] guerra se justifica eminentemente quando um povo recusa o uso e a posse de um solo a pessoas que, em virtude do direito resultante da natureza, deveriam ter do que se alimentar" (MORUS, 1997, p. 87).

$\mathrm{O}$ eurocentrismo de Mórus e o desconhecimento da dinâmica territorial mais profunda dos povos ditos primitivos eram enormes e se repetiriam nos escritos de vários outros pensadores, como em Rousseau, mais de 200 anos depois.

Mórus não aprofunda os fundamentos democráticos das cidades gregas. Prefere uma monarquia representativa, próxima da lógica maquiavélico-ratzeliana, ${ }^{24}$ ou seja, integração territorial, comunidade fundada na língua, costumes, história, submissão de estrangeiros se necessário.

Em síntese, o continente europeu viveu nos séculos $\mathrm{XV} / \mathrm{XVI}$ uma profunda reestruturação econômica e cultural que moldou sua vertiginosa expansão econômica e territorial apoiada em projetos de colonização para além do mediterrâneo. $\mathrm{O}$ crescimento demográfico associou-se à mobilização de milhões de trabalhadores negros e não europeus a serviço de um novo sistema econômico de feição internacional, alicerçado no enriquecimento da burguesia e no esta-

\footnotetext{
${ }^{24}$ A alusão a Ratzel é aqui estabelecida diante de suas teses sobre a geopolítica alemã ao tempo da unificação em fins do século XIX. Sobre o autor ver Moraes (1990).
} 
belecimento de Estados que se tornariam absolutos. Estava a Europa ensinando ao resto do mundo como equacionar a produção de riqueza com base em princípios racionais defendidos por um Estado laico, interventor, organizador do imaginário social, voltado para a exploração de recursos humanos e materiais?

\section{Tempo 4: Europeus dominam o mundo}

O quarto tempo histórico é o da imposição da supremacia europeia sobre o resto do mundo no século XIX. O impressionante dinamismo econômico pôs em marcha processos de grande magnitude: industrialização massiva, crescimento demográfico, emigração europeia, revoluções políticas, nacionalismo, afirmação do Estado-nação, neocolonialismo e disputas por recursos naturais.

De fato, o avanço industrial na Inglaterra mostrou-se rápido, tanto quanto seus efeitos dispersores pelo continente a partir de 1820. A explosão das taxas de crescimento industrial da Inglaterra a partir de 1800 representou um efeito-demonstração irresistível. As novas máquinas de fiação e tecelagem, a produção de ferro fundido e a máquina a vapor impactaram toda a economia e trouxeram, após $1830,{ }^{25}$ a grande indústria e o boom ferroviário, que fizeram do Reino Unido a principal área industrial do mundo.

Na chamada "2a Revolução Industrial", que se desenrola a partir de 1870 até a I Guerra Mundial, a indústria da maioria dos países europeus avançou muito na Rússia,
Itália, Suécia, entre outros. No último quartel do século, a corrida industrial constituía o pano de fundo do neocolonialismo. O desenvolvimento tecnológico e os desdobramentos das inovações na produção de aço e energia (eletricidade e petróleo) promoveram a revolução dos transportes e a queda de preços dos alimentos, estimulando as potências na busca de possessões dotadas de recursos minerais valiosos. Nesse momento a Alemanha, unificada desde 1871, passava a determinar o ritmo da corrida pela supremacia industrial, sobretudo na química e eletricidade. Surgiam novos hábitos de consumo que exponenciaram a circulação de ideias, mercadorias e pessoas. A emigração europeia e o translado forçado de milhões de africanos escravos para o Novo Mundo foram poderosos instrumentos de expansão e dominação econômico-cultural.

As violentas transformações políticas que deram forma definitiva aos atuais Estados nacionais, o forte crescimento demográfico da Europa à época e a emigração internacional ${ }^{26}$ contribuíram decisivamente para a ocidentalização do mundo com base na matriz europeia. Sem esses fatores fica difícil entender a geopolítica do mundo contemporâneo.

O século XIX trouxe o impressionante incremento demográfico mundial de cerca de 900 milhões de pessoas para pouco mais de 1,6 bilhão. Algumas estimativas indicam que, em um século, a população europeia evoluiu de 190 milhões para 423 milhões. Nos 100 anos anteriores a 1914, Reino Unido, Alemanha e EUA, os três principais

\footnotetext{
25 O clássico de T. S. Ashton (1977), ainda que invista mais que o necessário nos processos de inovação técnica, é atento aos processos históricos que precederam às grande mudanças, tais como: proliferação de bancos e firmas de pequeno porte em todo o período de relativa estabilidade interna no século XVIII; uma nova cultura otimista de acumulação que se irradiou a partir de Londres; inéditas obras de infraestrutura que fizeram expandir a rede de cidades comerciais e interiorizar o capitalismo na ilha; novas relações capital e trabalho; relações ultramarinas vantajosas e o grande surto de evolução econômica subsequente. Sobre a questão demográfica conviria destacar duas afirmativas do autor: a) "O aspecto mais saliente da história desse período [1760-1830] - aquilo que acima de tudo o distingue dos períodos anteriores - é o rápido crescimento da população [...] aumento [que] não resultou de qualquer alteração na taxa de natalidade [...] foi a baixa da mortalidade que provocou o aumento de habitantes" (ASHTON, 1977, p. 23-24), como resultado da combinação de vários fatores que o autor descreve em detalhes; b) O autor destacou as "vedações" e expulsão de camponeses de suas comunidades de origem, ao lado da emigração de milhares de ingleses para as colônias e ex-colônias e reposição de trabalhadores com a vinda de milhares de escoceses e irlandeses pobres para a Inglaterra de início do século XIX, momento em que foram superexplorados à época de constituição do trabalho assalariado e unificação do mercado de trabalho.

26 Em termos de migrações intraeuropeias, Hobsbawn (1996) menciona as intensas migrações internas na Inglaterra; a emigração de irlandeses em busca de trabalho em Liverpool, Glasgow e Manchester; as transferências de poloneses para as minas do Vale do Ruhr; e as migrações sazonais procedentes de diversas partes do continente.
} 
países industrializados, quase quintuplicaram suas populações. Entre 1810 e 1910, os europeus e seus descendentes aumentaram de 5,7 milhões para 200 milhões nas Américas, África do Sul, Austrália, Nova Zelândia e Sibéria. No início do século XX, estima-se que a população mundial distribuía-se assim (em milhões): Europa (423), Ásia (937), África (120), América do Norte e do Sul (144) e Austrália (6). Por volta de 1900, quando o crescimento populacional da Europa atingiu seu auge, a emigração para os Estados Unidos alcançou a incrível marca de um milhão de pessoas por ano. ${ }^{27}$

Muitos fatores explicam a grande expansão demográfica do período: avanços na produção industrial e agrícola associados à revolução dos transportes; extração mineral e agrícola ultramarina abastecendo a Europa de matérias-primas e alimentos; desaparecimento das grandes crises de mortalidade na Europa; progresso da medicina; e adoção de padrões de higiene pessoal e consequente redução da mortalidade por cólera, tifo, varíola e tuberculose.

Durante o Oitocentos os líderes da emigração foram Reino Unido, Alemanha, Itália, Polônia, Rússia, além dos países escandinavos, Bélgica e Espanha. Com isso a população branca expandiu-se de $22 \%$ em 1800 para $35 \%$ em 1930 . O aspecto mais importante nesse processo foi a chegada de milhões de pessoas às Américas, África do Sul, Austrália e Nova Zelândia. $O$ expansionismo europeu alcançou as mais diferentes regiões do mundo e mobilizou os recentes Estados nacionais na busca por recursos minerais estratégicos.

Os britânicos, além das antigas possessões, anexaram novas terras ao seu vasto império, chegando a controlar $20 \%$ dos territórios e $25 \%$ da população mundial. Já a França ostentava um império de 10,4 milhões de $\mathrm{km}^{2}$ e 47 milhões de pessoas, enquanto a Alemanha, que chegara atrasada na corrida neocolonial, abocanhou 2,6 milhões de $\mathrm{km}^{2}$ e conquistou 14 milhões de súditos. Além dessas potências, participaram do mesmo processo Itália, Portugal, Rússia, Japão e até os EUA, com a ocupação do oeste californiano, Novo México e Porto Rico.

Mas o século XX não teria posto fim no expansionismo territorial dos europeus, inclusive pelas duras consequências resultantes da corrida imperialista? De fato, o novo século, além de introduzir o protagonismo americano não atrelado ao territorialismo, como mostra Giovanini Arrigui (1996), trouxe grandes mudanças econômicas atreladas a três eventos que dilaceraram o Velho Mundo: duas guerras mundiais; e a longa depressão resultante da crise de 1929. As guerras depauperaram as principais nações beligerantes, liquidaram com velhas pretensões expansionistas, trouxeram cenários de crise e desolação, em meio a saídas massivas de europeus para a América e o drama dos refugiados de guerra. Essas catástrofes fizeram expandir a indústria nos setores químico, automotivo e na aviação, deram origem à grande indústria bélica americana, provocaram enormes perdas populacionais, o fim dos impérios austro-húngaro, otomano e russo-czarista e iniciaram um longo período de sangrentos conflitos nas guerras de independência na África.

\section{De volta ao caso chinês}

Após o que foi até aqui retratado, caberia indagar se o expansionismo de corte territorial foi liquidado ou permanece oculto sobre novas roupagens. Estaria dissociado dos recursos naturais e dos estoques populacionais como fonte de poder? Como vincular tudo isso com o atual crescimento da China? Ela se apropriou do exemplo histórico europeu?

Certamente a República da China Popular é um bom exemplo para discutir as questões supracitadas, porque é um grande território que se vale de seus recursos naturais, de sua grande população e de sua

27 Para aprofundar os dados a seguir mencionados, ver: Patarra (1995), Hobsbawm (1996), Vainer (1995, p. 44), Folha de S.Paulo (18/07/1991), Lessa (2001) e Atlas da História do Mundo (1995). 
cultura milenar não ocidental, que também percorreu a trajetória de afirmação dos povos de civilização densa. Uma síntese de resposta para o entendimento do chamado "milagre" chinês deve levantar fatores indissociáveis, tais como: geopolítica e comércio internacional em um Estado interventor; recursos naturais utilizados na produção de infraestruturas, energia e insumos básicos; e recursos populacionais como força de trabalho barata. Detalhando um pouco mais:

- Geopolítica estadunidense e comércio internacional. Visando isolar a URSS, os americanos contaram com o apoio da China nas reformas de Deng Xiaping. Os estímulos à instalação de empresas americanas significaram ingresso do país no mercado internacional mediante inéditas parcerias empresariais. Isso iria favorecer a apropriação de tecnologia industrial, sem abalar o aparato estatal do regime de partido único. Mais tarde, uma vez deslanchado o processo de expansão econômica e a China já integrante do clube atômico, triunfam seus interesses em negociações econômicas com a União Europeia, Japão, países da bacia do Pacífico, África e América do Sul. $\mathrm{Na}$ bacia do Pacífico, a China mobilizou países como Taiwan, Coreia do Sul e Japão, tornando-os dependentes de seu dinamismo. A abertura econômica disseminou nas zonas de desenvolvimento preferencial: joint ventures e outras formas de associação de empresas locais e estrangeiras; concessão de incentivos fiscais e acesso a infraestrutura de transportes, água e eletricidade; favorecimento às empresas que transferissem tecnologia em setores avançados; redução de restrições legais na aquisição de ativos e participação majoritária de empresas chinesas. Com isso, entre 1990 e 2003, entraram no país quase
500 bilhões de dólares em investimento direto e surgiram parcerias com multinacionais do setor mineral, a fim de cobrir a demanda de ferro, cobre, aço, alumínio e petróleo.

- Investimentos em infraestrutura e mão de obra abundante e barata. Pesados recursos financeiros manipulados pelo Estado foram investidos em obras de infraestrutura (estradas, portos, aeroportos e novas cidades), na produção de ferro, aço, cimento, carvão e petróleo. Nesse ambiente foi construída a maior hidrelétrica do mundo, a controvertida Três Gargantas. No tocante à mão de obra, o país usufrui da enorme vantagem comparativa em termos de força de trabalho numerosa, disciplinada, mal remunerada e ainda disposta a se submeter a duras condições de trabalho nas milhares de fábricas que se multiplicam no país, especialmente no delta do Rio Pearl, que congrega milhões de trabalhadores nas cidades de Shunde, Shennzhen, Dongguan, Zhongshan e Zhuhai, especializadas em produtos de consumo moderno.

A China incrementou sua posição estratégica na região, o que teria facultado o estabelecimento de pequenas colônias na Ásia (Cazaquistão, Laos e extremo oriente russo), a fim de suprir sua demanda por alimentos e compensar a declinante produção de grãos, além de fixar parte de sua população campesina excedente. Fora da região, Brasil e países sul-americanos também participam dessa reconfiguração geopolítica no comércio mundial. ${ }^{28}$

Resta indagar se esse expansionismo continuará nas próximas décadas. Diante da alta taxa de exploração da força de trabalho, da ausência de direitos trabalhistas e dos requerimentos de produtividade que a competitividade internacional exige, surgem indagações sobre as consequências do atual incremento da escolarização e da formação

\footnotetext{
${ }^{28}$ No Brasil, discreta, silenciosa e dispersamente se multiplicam os núcleos de imigrantes chineses. Segundo a embaixada brasileira da República Popular da China, há cerca de 250 mil chineses no país, 200 mil apenas em São Paulo ocupados no comércio de importação de mercadorias (FOLHA DE S.PAULO 26/09/2010).
} 
técnica de milhões de chineses. Essa nova mão de obra qualificada irá suportar baixos salários e acomodar-se à submissão e precarização das atuais condições de trabalho?

\section{Conclusões e considerações finais}

Rupturas históricas e grandes mudanças em regiões que ingressaram na modernidade podem fazer crer que os constrangimentos do passado que cerceavam a vida humana e limitavam a produção de riquezas desapareceram. Daí certa crença de que fatores decisivos para a sobrevivência das sociedades pré-industriais, como dotação de recursos naturais e estoques populacionais tornaram-se ultrapassados diante da chamada sociedade do conhecimento, que resolveriam as carências de países com déficits de recursos humanos ou materiais.

No mundo da financeirização do capitalismo internacional, foi moda nos anos 1980/90 a ideia da sobredeterminação da globalização financeira e industrial, do fim dos Estados nacionais e, para alguns neoliberais, a aposta de que ganhos especulativos excepcionais poderiam sustentar a prosperidade de países, sem a necessidade de mobilização de capitais produtivos, mão de obra, planejamento e regulação do Estado.

As reflexões aqui expostas divergem dessas ideias e procuraram por em destaque a importância histórica e atual do poder organizado no interior dos Estados, dos recursos naturais na subsistência, produção energética e de riquezas, ao lado da disponibilidade de estoques populacionais capazes de viabilizar a reprodução econômica. Dessa forma, estamos longe da perspectiva malthusiana ou neomalthusiana que ignora o alcance de estruturas de poder amalgamadas a heranças culturais de povos expansionistas que utilizaram os recursos de subsistência e preeminência em projetos de conquista ou de defesa de territórios.

Espaços ocupados, populações em crescimento, recursos naturais disponíveis e formas de poder instituídas são instâncias primordiais indissociáveis que sempre influíram na dinâmica econômica e na geopolítica mundial. $\mathrm{O}$ crescimento demográfico por si só atestava a robustez de determinado povo e era geralmente bem-vindo se os governantes vislumbrassem a possibilidade de sua acomodação nos territórios disponíveis. Em caso contrário, o controle da natalidade era praticado sob diversas formas, como faziam os "civilizados" gregos e demais povos da antiguidade. Com o avanço das três grandes religiões monoteístas, as restrições morais e a suspeição que se abateu sobre as mulheres, ficaram interditadas uma série de práticas abortivas e o crescimento demográfico amalgamou-se aos projetos de evangelização dos povos "bárbaros".

A conjunção do poder eclesiástico com o poder temporal da realeza viabilizou em largas porções do planeta a conquista de territórios e "almas", novos mercados e súditos. Os europeus foram os mais bemsucedidos nessa empreitada, particularmente entre os séculos XVI e XIX, período em que disseminam internacionalmente leis, acordos, arranjos jurídicos, empresas sob a égide da expansão mundial do capitalismo industrial.

$\mathrm{Na}$ proposta aqui apresentada quatro tempos históricos foram destacados. No tempo 1 , recursos naturais essenciais à sobrevivência e aumento dos estoques populacionais introduziram complexidade histórica crescente nas sociedades que galgaram o neolítico e se estabeleceram com base no domínio da agricultura e do comércio. A sedentarização fez reduzir os deslocamentos em busca de comida, diminuiu as restrições à fecundidade e permitiu o aumento da população em regiões que ainda hoje são populosas. Nesse processo, a expansão territorial ganhou novo ímpeto, o comércio, a vida urbana e a organização sociopolítica deram origem a vários impérios, onde os recursos de proeminência passaram a balizar a vida econômica. Um longo período de guerras de conquistas e anexações se iniciou, mas acompanhado de derrocadas associadas com o esgotamento de recursos naturais e crises cíclicas de mortalidade.

No tempo 2, continuaram imbricados a tríade poder, recursos naturais e população, particularmente nas redes comerciais do Mediterrâneo, sob a influência grega e romana. As Cidades-estado participavam 
da expansão territorial e comercial como pilares da economia política descrita por Platão e Aristóteles. Novas concepções de mundo a partir da observação da natureza, do advento da ciência, democracia e direitos marcariam a história do Ocidente. O crescimento demográfico além do considerado ideal poderia comprometer a "governabilidade" e exigir a fundação de novas colônias na periferia. Com isso, incrementam-se os aparatos militares, os equipamentos, armas e adestramento, para defender terras e mares conquistados.

No tempo 3, o conjunto de mudanças deixa mais enfáticas as grandes transformações econômicas na Europa, desde as navegações transoceânicas e reestruturações comerciais e territoriais. Surgem as economias-mundo no Mediterrâneo e Mar do Norte e, com a expansão marítima, o continente absorve formidáveis recursos de subsistência e proeminência oriundos do Novo Mundo, da África e Índia. O crescimento demográfico incrementou-se e a política reorienta-se na prática e na teoria. Tomas Morus e Nicolau Maquiavel atuam na formação de novas consciências, prescrevem a racionalidade do Estado laico, normas regulatórias associadas à expansão territorial, colonização, guerras de conquista, disciplina e treinamento militar. O conhecimento da história e geografia dos territórios em disputa é conveniente ao eurocentrismo em expansão.

O tempo 4 é o da supremacia europeia sobre o resto do mundo no século XIX. O impressionante dinamismo econômico, industrialização massiva e economias de mercados internacionalizadas geraram uma nova corrida colonialista rumo aos recursos naturais que se tornaram estratégicos em fins do século XIX. As disputas territoriais, o inusitado crescimento demográfico e a emigração europeia permitiram a consolidação de revoluções políticas e econômicas e a afirmação dos Estados nacionais.

A despeito da complexidade do mundo sob o domínio inglês, os três fatores aqui discutidos assumiram pronunciada relevância na tessitura dos projetos de expansão protagonizados por países europeus que marchavam rapidamente em direção à in- dustrialização. O crescimento demográfico não teve paralelo na história europeia, especialmente após o fim das grandes crises de mortalidade, o que permitiu a exportação de súditos para o resto do mundo e o aumento de possessões territoriais que ajudaram a firmar a hegemonia mundial do continente por décadas. Uma esfera mundial de interesses geopolíticos foi estruturada a partir do século XIX que, em essência, está vigente até hoje.

O que foi aqui apresentado suscita reflexões sobre novas roupagens que o ideário expansionista poderia estar assumindo, ainda que não exclusivamente de cunho territorialista. Todavia, é duvidoso minimizar a combinação em tríade poder, recursos e população. Vimos como a China vem se inserindo no capitalismo mundial, sua postura desenvolvimentista, as ameaças aos blocos hegemônicos atualmente em crise. Estaria ela se apropriando do exemplo Ocidental? Nos jogos olímpicos de 2008, não teria procurado demonstrar ao mundo sua força, majestade e grandeza histórico-cultural em um espetáculo similar a tantos outros de pompa e magnificência que o Ocidente expõe ao mundo há tanto tempo?

Certas questões continuam recorrentes. Os exemplos atuais insistem em deixar presentes os fatores aqui arrolados. Senão, como compreender o Egito e o norte da África hoje, peças-chave da geopolítica mundial? Como entender a comoção social, as grandes rebeliões e sede de mudanças no Egito, sem considerar o contingente de jovens escolarizados de classe média que a dinâmica demográfica trouxe à vida adulta, mas sem perspectivas de emprego e inserção política, ignorados pela plutocracia, que há décadas amealhava os dividendos do petróleo, dos ganhos do Canal de Suez, dos crescentes aumentos do PIB da segunda maior economia do continente, sem erradicar a pobreza e exclusão?

Do ponto de vista das heranças que persistem no imaginário social, há fortes indícios de que uma memória coletiva grandiloquente realimenta antigas crenças, mitos fundadores, imagens heroicas que valorizam a força do povo ou nação, inculcados por formadores de opinião e por segmentos remanescentes das elites 
fundadoras da cultura nacional. Nesse ambiente, subjetividades pouco racionais sobrevivem e nunca se contentam com a não expansão, nunca dispensam a ideia da maximização das oportunidades, dos lucros e vantagens. A cultura histórico-econômica faz crer que o único caminho é o do contínuo progresso e crescimento. A perspectiva do não crescimento ou apenas manutenção do que foi conquistado soa como regressista ou conservadora. Com isso fica subjacente o primado da força e expansão a todo custo, não raro a custa de populações tradicionais, que não desenvolveram sistemas de defesa

ALVES, J.E.D. A polêmica Malthus versus Condorcet reavaliada à luz da transição demográfica.Rio de Janeiro: IBGE/Escola Nacional de Ciências Estatísticas, 2002 (Textos para discussão).

ARRIGHI, G. O longo século XX. São Paulo: Contraponto, Unesp. 1996.

ASHTON, T. S. A revolução industrial; 1760-1830. 4a ed. Mira-Sintra, Portugal: Publicações Europa-América, Europan, 1977.

ATLAS da história do mundo. 4a ed. da "Times Books". Folha de S.Paulo, 1995.

ATLAS de história mundial. Rio de Janeiro: Reader's Digest Brasil, 2001. Adaptação das edições inglesa e francesa de The times history of the word.

BEN-PORATH, Y. The F-conection: families, friends, and firms and the organization of exchange. Populationand Development Review, v. 6, n. 1, p. 1-30, Mar. 1980.

BIDEAU, A. Mecanismos auto-reguladores de populações tradicionais. In: MARCíLIO, M.L. (Org.). População e sociedade: evolução das sociedades pré-industriais. Petrópolis: Vozes, 1984, p. 47-68.

BIRABEN, J.-N. Epidemias na história da população. In: MARCÍlIO, M. L. (Org.). População e sociedade: evolução das sociedades pré-industriais. Petrópolis: Vozes, 1984, p. 110-136.

BLACKBURN, S. A República de Platão e ataque sofisticados como os dos países ricos. Ainda hoje, quando as grandes conflagrações mundiais tornam-se distantes, investimentos em armas e mecanismos de defesa parecem uma imposição inelutável em todos os países. Nesse ambiente ideológico, ideários que chamam atenção para os desequilíbrios ecológicos, novas matrizes energéticas e tecnológicas, direitos humanos, democracia participativa e empoderamento feminino soam marginais e prosperam com muita dificuldade.

\section{Referências}

(uma biografia). Rio de Janeiro: Zahar, 2008.

BOSERUP, E. Evolução agrária e pressão demográfica. São Paulo: Editora Hucitec/ Editora Polis, 1987.

BRAUDEL, F. Civilização material, economia e capitalismo: séculos XV-XVIII. São Paulo: Martins Fontes, 1995-1996.

BRETON, R. J. L. Geografia das civilizações. São Paulo: Ática, 1990.

CALDWELL, J. Theory of fertility decline. New York: Academic Press INC, 1982.

CHANG, J. Cisnes selvagens; três filhas da China. São Paulo: Companhia das Letras, 1996.

COALE, A.The demographic transition: a summary, some lessons and some observations. In: CHO, L.; KOBAYASHI, K. (Eds.). Fertility transition of East Asian populations. Honolulu: University Press of Hawaii, 1979, cap. 2.

COOK, M. Uma breve história do homem. Rio de Janeiro: Zahar, 2005.

DIAMOND, J. Armas, germes e aço. Rio de Janeiro: Record, 2009.

DOBB, M. A evolução do capitalismo. 3a ed. Rio de Janeiro: Zahar, 1973.

FOLHA DE S.PAULO. Caderno especial sobre migrações. 18/07/1991. 
GALBRAITH, J.K. Anatomia do poder. São Paulo: Pioneira, 1986.

HAJNAL, J. Two kinds of pre-industrial household formation system. Population and Development Review, v. 8, n. 3, p. 449-94, set. 1982.

HOBBES, T. Leviatã ou a matéria, forma e poder de um Estado eclesiástico e civil. $4^{\text {a }}$ ed. São Paulo: Nova Cultural, 1988 (Coleção Os pensadores).

HOBSBAWN, E. A era das revoluções: Europa 1789-1848. 2a ed. São Paulo: Paz e Terra, 1997.

A era do capital, 1848-1875. $2^{\mathrm{a}}$ ed. Rio de Janeiro: Paz e Terra, 1996.

LASLETT, P. Introduction: the history of the family. In: LASLETT, P.; WALL, R. (Eds.). Household and family in past time. Cambridge: Cambridge University Press, 1974.

LEAKEY, R. E. A evolução da humanidade. $2^{\mathrm{a}}$ ed. São Paulo: Melhoramentos, 1982.

LESSA, A. V. M. Atlas da história mundial. Rio de Janeiro: Reader's Digest Brasil, 2001.

LIVI-BACCI, M. A concise history of world population. Blackwell, Cambridge University Press, 1992.

MACFARLANE, A. A cultura do capitalismo. Rio de Janeiro: Zahar, 1989.

História do casamento e do amor; Inglaterra, 1300-1840. São Paulo: Companhia das Letras, 1990.

MALTHUS, T. Ensaio sobre o princípio da população. São Paulo: Ática, 1983 (Coleção Grandes Cientistas Sociais, 24).

McNICOOL, G. Institucional determinants of fertility change. Population and Development Review, v. 6, n. 3, p. 441-62, set. 1980.

MORAES, A. C. R. (Org.). Ratzel. São Paulo: Editora Ática, 1990.

MORUS, T. A Utopia. São Paulo: L\&PM Editores, 1997.

MUNFORD, L. A cidade na historia. Belo Horizonte: Itatiaia, 1965

NEMO, P. O que é o ocidente? São Paulo: Martins Fontes, 2005 (Coleção Dialética).
O'REILLY, K.R. Contraception, ideology, and policy formation: cohort change in Dublin, Ireland. In: HANDWERKER, W.P. Culture and reproduction; an anthropological critique of demographic transition theory. Colorado (USA): Westview Press, 1986.

PAIVA, P. T. A. O processo de proletarização e a transição da fecundidade no Brasil. Revista Brasileira de Economia, v. 41, n. 4, p. 383-414, out./dez. 1987.

PATARRA, N. Emigração e imigração internacionais no Brasil contemporâneo. Campinas: FNUAP, 1995.

PIRRENE, $\mathrm{H}$. História econômica e social da Idade Média. São Paulo: Mestre Jou, 1978.

POTTER, J. E. Effects of societal and comunity institutions on fertility. In: BULATAO, R.; LEE, R. (Eds.). Determinants of fertility in developing countries. New York: Academic Press, v. 2, 1983.

RAMOS, F. P. No tempo das especiarias; o império da pimenta e do açúcar. São Paulo: Contexto, 2004.

STAMM, L.; TSUI, A. O. Cultural constraints on fertility transition in Tunisia. In: HANDWERKER, W.P. Culture and reproduction; an anthropological critique of demographic transition theory. Colorado (USA): Westview Press, 1986.

VAINER, C. B. A perspectiva da sociologia sobre migrações internacionais atuais. Lisboa: Universidade Aberta, 1995.

WALLERSTEIN, I.The modern worldsystem: capitalist agriculture and the origins of the European world-economy in the sixteenth century. New York/London: Academic Press, v. 1, 1974.

Sistemas históricos como sistemas complexos. México d.f: SigloVeintiuno, 1998.

WEBER, M. Economia e sociedade. São Paulo: Editora UNB, 2004.

WRIGLEY, E. A. (Ed.). An introduction to English historical demography from the sixteenth to the nineteenth century. New York: Basic Books, 1966. 


\section{Resumen}

Población, recursos naturales y poder territorializado: una perspectiva teórica supratemporal

Este ensayo discute relaciones sociopolíticas y territoriales que recubren la dinámica demográfica, los recursos naturales y el ejercicio del poder en distintos momentos históricos. La reflexión sobre la China contemporánea y su desarrollo económico fuertemente consumidor de recursos naturales sirve como parámetro para establecer conexiones con otros tiempos históricos en los que la combinación en tríada poder, recursos y población siempre estuvo presente. Se subrayan cuatro tiempos históricos: el del paso del Pleistoceno al Holoceno; el del florecimiento de la civilización griega; el de la restructuración europea del siglo XVI; y el del impulso industrializador a partir de fines del siglo XVIII, que introdujo un largo período de hegemonía económica europea. Formas de poder político, población y los recursos de subsistencia y prominencia son cruciales para el entendimiento del tejido de proyectos de expansión protagonizados por países europeos y no europeos, especialmente desde el siglo $\mathrm{XIX}$, momento en el que rivalidades e intereses geopolíticos se hacen explosivos y estructuran divisiones internacionales del trabajo que se reprodujeron durante mucho tiempo. Los análisis y ejemplos presentados permiten indagar si el ideario expansionista no asumiría en la actualidad nuevos ropajes, aunque ya no exclusivamente territorialista. Hay fuertes indicios de que una memoria colectiva grandilocuente realimenta antiguos mitos fundadores que valorizan identidades nacionales en ambientes de poca racionalidad, en los cuales la perspectiva de maximización de ganancia y oportunidades contagia a todos.

Palabras Clave: Población y historia. Población y recursos. Población y geopolítica.

\section{Abstract \\ Population, natural resources and territorialized power: a supratemporal theoretical perspective}

The present analysis discusses the sociopolitical and territorial relations that cover the demographic dynamics, natural resources and exercising power at different historical moments. The reflections on contemporary China and its economic development as a strong consumer of natural resources is a parameter for establishing connections with other historical periods in which the combination of power, resources and population as a triad has always been present. Four historical periods are underscored: the passage from Pleistocene to Holocene; the flourishing of the Greek civilization; the 16th Century European restructuring; and the industrializing spurt as of the end of the $18^{\text {th }}$ Century, which introduced a long period of European economic hegemony. Structures of political power, population, and of resources of survival and prominence are crucial in order to understand the organization of expansion projects led by European and non-European countries, especially beginning the 19th century, a moment in which rivalries and geopolitical interests became explosive and organized international labor divisions that reproduced themselves extensively. The analyses and examples described allow questioning if the expansionist ideary is not currently taking over new features, even if no longer exclusively territorialist. There is strong evidence that the grandiloquent collective memory rekindles ancient founding myths that value national identities in barely rational environments, in which the perspective of maximizing profits and opportunities is compelling.

Keywords: Population and history. Population and resources. Population and geopolitics. 